KS. WALDEMAR W. ŻUREK SDB* - LUBLIN

\title{
WIZYTACJA KOŚCIOLA PARAFIALNEGO W KROSZYNIE W DIECEZJI WILEŃSKIEJ Z 1820 ROKU
}

Polskie miasteczko kresowe, obecnie wieś Kroszyn położone jest na Białorusi (biał. Kрошын), w obwodzie (województwie) brzeskim, w rejonie (powiecie) baranowickim. Leży na prawym brzegu rzeki Szczary, lewym dopływie Niemna.

W średniowieczu Kroszyn był siedzibą rodową książąt Kroszyńskich. W XVIII i XIX wieku dziedzicami Kroszyna byli Prószyńscy, po nich m.in. Radziwiłłowie, Giedroyciowie i Zawadzcy, którzy w ocalałej oficynie mieszkali do 1939 roku. Obszerny dwór (wcześniej zamek obronny), w którym zgromadzono zbiory biblioteczne, archiwum, obrazy i pamiątki, spłonął w 1915 roku wraz $\mathrm{z}$ dobytkiem. Ocalała jedynie oficyna.

Początki katolickiej parafii pw. Bożego Ciała i świętych Grzegorza i Mikołaja sięgają 1442 roku, której drewniany kościół wybudował i ufundował Juszko Gojcewicz ${ }^{1}$, za rządów biskupa wileńskiego Macieja z Trok (1422-1453)². W okresie staropolskim parafia kroszyńska należała do diecezji wileńskiej, dekanat Słonim i posiadała patronat szlachecki. Tamtejszy drewniany kościół parafialny spłonął w 1791 roku. Parafia kroszyńska liczyła wówczas 1409 wiernych. Odbudowany przez proboszcza Wojciecha Magnuszewskiego drewniany kościół został poświę-

* Ks. Waldemar W. Żurek SDB - dr hab. historii Kościoła; prof. KUL; dyrektor Ośrodka Archiwów, Bibliotek i Muzeów Kościelnych KUL; e-mail: zurek@kul.pl

${ }^{1}$ Gojcewicz Juszko/Hojcewicz Jerzy, według dokumentów z 1567 roku był właścicielem wsi Juszkiewicze, która należała do majątku Czernichowo w parafii kroszyńskiej.

${ }^{2}$ Maciej, Maciej z Wilna, Maciej z Trok - biskup, urodził się ok. 1384 roku w Wilnie. Pochodził z inflandzkiej rodziny. Był uczniem Jana Husa w Pradze. Od wielkiego księcia Witolda otrzymał nominację na ordynariusza diecezji żmudzkiej. Po śmierci biskupa wieleńskiego Piotra Jastrzębca rozpoczął w 1421 roku starania o translację do Wilna, co potwierdził w 1422 roku papież Marcin V. W tym roku pobłogosławił w Nowogródku małżeństwo króla Władysława Jagiełły II z Zofią. W Wilnie ustanowił inkwizycję przeciw husytom. Od kandydatów do kapłaństwa wymagał znajomości języka litewskiego. Był jedną z najbardziej wpływowych osób na Litwie. Popierał starania Witolda o koronę królewską. Ostatecznie opowiadał się za Jagiellonami na tronie wielkoksiążęcym i za unią z Polską. S. Brzozecki, Maciej, Maciej z Wilna, Maciej z Trok, w: Encyklopedia Katolicka (dalej: EK), t. 11, Lublin 2006, kol. 705-706. 
cony w 1821 roku $^{3}$ Świątynia kroszyńska spłonęła w czasie I wojny światowej - w 1915 roku. Nowy kościół wymurowany w 1931 roku staraniem parafian i proboszcza ks. Jana Borodzicza, został poświęcony dnia 28 VI 1931 roku przez bpa Zygmunta Łozińskiego ${ }^{4}$. Po erygowaniu w 1925 roku diecezji pińskiej, parafia kroszyńska należała do tej administracji kościelnej ${ }^{5}$.

W II Rzeczypospolitej Kroszyn należał do gminy Stołowicze, w województwie nowogródzkim, w powiecie baranowickim. Po II wojnie światowej znalazł się za granicą wschodnią Rzeczypospolitej Polskiej, w strukturach administracyjnych Związku Radzieckiego - Białoruskiej Socjalistycznej Republice Radzieckiej. Od 1991 roku Kroszyn położony jest granicach Republiki Białorusi.

$$
* * *
$$

Opis fizyczny dokumentu rękopiśmiennego: Rękopis: „Wizyty jeneralnej catego funduszu kościoła parafialnego kroszyńskiego w roku 1820 odbyta", pochodzący z Archiwum Diecezjalnego w Drohiczynie, Zespół Archiwum Parafii Kroszyn (sygn. III/I/1), jest opisem stanu kościoła parafialnego do momentu generalnej wizytacji w 1820 roku.

Dokument o wymiarach: $320 \times 212 \mathrm{~mm}$ ma formę składki (sześciu kart zszytych ze sobą $\mathrm{w}$ miejscu złożenia lnianą nicią), złożonej z dwunastu niefoliowanych kart oprawionych $\mathrm{w}$ tekturowe okładki obciągnięte papierem marmurkowym w kolorach różowym i zielonym oraz tzw. półskórek (grzbiet i rogi). W centralnej części okładki została naklejona finezyjnie wycięta naklejka tytułowa z wykaligrafowaną nazwą: Wizyta jeneralna całego funduszu kościoła

${ }^{3}$ S. Litak, Kościót łaciński w Rzeczypospolitej około 1772 roku, Lublin 1996, s. 326.

${ }^{4}$ Łoziński Zygmunt (1870-1932) - teolog, ordynariusz reaktywowanej diecezji mińskiej, pierwszy biskup diecezji pińskiej, sługa Boży. Urodził się na ziemi Nowogródzkiej, zmarł w Pińsku. W 1889 roku wstąpił do seminarium duchownego w Petersburgu, kontynuował studia w Akademii Duchownej w Petersburgu, w 1895 roku przyjął święcenia kapłańskie. W pracy duszpasterskiej angażował się w pracę z młodzieżą akademicką. Został skazany na dwa lata na banicję w klasztorze karnym w Agłomie na Łotwie. Po ułaskawieniu w 1900 roku pracował jako wikariusz w Smoleńsku, Tule, Rzydze. W 1904 roku został proboszczem w Kalwarii koło Mińska, następnie parafii katedralnej w Mińsku. Za tamtejsze zaangażowanie na rzecz Polaków i unitów, został usunięty z Mińska. Był wykładowcą w seminarium w Petersburgu, studiował biblistykę w Monachium, Rzymie, Jerozolimie i ponownie w Rzymie. W 1913 roku ponownie podjął wykłady seminaryjne w Petersburgu. W czasie I wojny światowej był kapelanem jeńców wojennych, członkiem Polskiej Organizacji Wojskowej w Rosji oraz brał udział w formowaniu armii polskiej. W 1917 roku został ordynariuszem reaktywowanej diecezji mińskiej. Sakrę biskupią przyjął 28 lipca 1918 roku w Warszawie. Po wejściu w grudniu 1918 roku Armii Czerwonej do Mińska ukrywał się. Po proklamowaniu w 1919 roku Białoruskiej SRR został aresztowany. Zwolniony został na mocy traktatu ryskiego w 1921 roku. Osiadł w Nowogródku gdzie organizował życie religijne polskiej części diecezji mińskiej. W 1925 roku został pierwszym ordynariuszem diecezji pińskiej. W 1929 roku zwołał do Pińska pierwszy synod diecezjalny. Proces beatyfikacyjny zmarłego w opinii świętości biskupa Łozińskiego rozpoczął się w 1957 roku w Rzymie. J. Misiurek, Łoziński Zygmunt, EK, t. 11, Lublin 2006, kol. 554-555.

${ }^{5}$ J. Kurczewski, Biskupstwo Wileńskie, Wilno 1912, s. 29, 304; Słownik Geograficzny Królestwa Polskiego i innych krajów stowiańskich, t. 4, red. F. Sulmierski, Warszawa 1883, s. 710-711. 
parafialnego kroszyńskiego, skutkiem ukazu konsystarza wileńskiego 1820 roku odbyta; dodatkowo umieszczono dwie naklejki sygnaturowe Archiwum Parafii Kroszyn (jedna grzbietowa u góry, druga równolegle do tytułu).

Rękopis sporządzony został brązowym atramentem na papierze czerpanym, żeberkowym, z widocznymi filigranami.

Dokument napisany jest $\mathrm{w}$ języku polskim, starannym charakterem pisma. Tekst na każdej karcie zakomponowany został w ramce; zawiera wykazy i rozbudowane tabele. Podziały tematyczne zostały wyodrębnione podkreślonymi nagłówkami. Na karcie pierwszej u góry został powtórzony tytuł dokumentu; na stronie dwunastej zostały odciśnięte pieczęcie: jedna czarna, tuszowa - dekanatu nowogródzkiego, druga, czerwona lakowa - herbowa wizytatora księdza Ludwika Pawłowskiego. Na tylnej wyklejce znajdują się zapiski różniące się od reszty dokumentu charakterem pisma, wykonane prawdopodobnie ołówkiem kopiowym.

Stan zachowania dokumentu w listopadzie 2015 roku jest dosyć dobry. Wewnętrzne karty są stosunkowo czyste i nieuszkodzone, składka natomiast niemal oderwana od oprawy. Na okładce papier obłóczkowy jest miejscowo przetarty, dają się zauważyć nieliczne otwory po owadach. Na wyklejkach widoczne są przebarwienia papieru spowodowane ingerencją mikrobów (pleśn i grzyby).

Dokument jest zabezpieczony tekturową teczką, opatrzoną naklejkami sygnaturowymi.

\section{TEKST DOKUMENTU}

[k. 1r] „Wizyta jeneralna całego funduszu kościoła parafialnego kroszyńskiego w roku $1820^{\mathrm{m}}$ odbyta".

[k. 2r] Wizyta całego funduszu kościoła parafialnego kroszyńskiego, diecezji wileńskiej, guberni grodzieńskiej, powiatu i dekanatu nowogródzkiego za rok $1820^{\mathrm{ty}}$, skutkiem ukazu wileńskiego rzymskokatolickiego konsystorza oddziału rządowego za № $3392^{\mathrm{m}}$ Julii $31^{\circ}$ dnia, w teraźniejszem $1820^{\mathrm{m}}$ roku danego sporządzona.

\section{1ํㅡㄹ Opisanie kościoła}

Kościół parafialny kroszyński, należący do plebanii kroszyńskiej pod tytułem Przenajświętszego Sakramentu, początkowo ufundowany od S. P. J[aśnie] Pana [Juszko] Goycewicza w roku $1442^{\mathrm{m}}$. Ten przez zeszłego J[egomości] księdza Karmazynowicza, wówczas proboszcza kroszyńskiego, z drzewa brusowego na nowo postawionym został, który za dzierżenia zeszłego J[egomości] Ks[ię] dza Karola Malinowskiego ${ }^{6}$ ostatniego poprzednika w czasie pożaru w $\mathrm{R}^{\underline{u}} 1791$

${ }^{6}$ Malinowski Karol (1741- po 1796) - pochodził z Podlasia, w 1755 roku wstąpił do jezuitów w Wilnie, święcenia przyjął w 1769 roku w Grodnie. Filozofię i teologię studiował w Wilnie, Grodnie i ponownie w Wilnie w latach 1761-1770. Następnie był profesorem wileńskiego Collegium Nobilium. Po kasacie zakonu został proboszczem w Nowym Dworze koło Grodna i wizytatorem szkół 
ogniem spłonął. Na miejscu tego szopę z kruhlakow ${ }^{7}$ słomą krytą wewnątrz bez stolowania i posadzki, o jednym ołtarzu tylko postawioną, dotąd za kościoł utrzymywano. Dopiero nowy, niedawno ukończony, wkrótce maiący się poświęcić [na marginesie dopisane: 1821 roku maja 23 poświęcony] przez W[ielmożnego] J[egomości] Ks[ię]dza Wojciecha Magnuszewskiego ${ }^{8}$ plebana kroszyńskiego te-

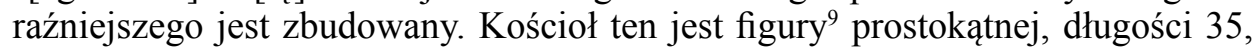
a szerokości 16 łokci mający $-\mathrm{z}$ drzewa brusowego nowego wystawiony, gątami kryty, z dwoma krzyżami zewnątrz nad dachem: jednym żelaznym, drugim drewnianym, blachą miedzianą pobielaną obitym, wyniesionemi - od frontu pobielany z czterma kolumnami murowanemi facjatę podpieraiącemi, na której odmalowany obraz Opatrzności Boskiej z napisem Gloria in excelsis Deo. Cały jest na fundamętach kamiennych i podmurowaniu wzniesiony. Wewnątrz całe prezbiterium i dwa ołtarze poboczne malowane - reszta zaś kościoła u dołu olejno w cegiełkę malowana, $w$ górze $\mathrm{z}$ klejem wybielona. Obok prezbiterium na obu stronach są dwie zakrystie, nad każdą $\mathrm{z}$ nich znajduje się galeryjka $\mathrm{z}$ balaskami ${ }^{10}$, $\mathrm{z}$ której wchodzi się na ambonę, równo z chórem wyniesioną, także malowaną. Drzwi wszystkie w tym kościele zamczyste, biało pokostowane, a ławki po obu stronach, konfesjonały i chór, w prezbiterium olejno $\mathrm{z}$ farbami malowane. Okien z szkła nowego w całym kościele z zakrystiami jedenaście. Podłoga z tarcic ${ }^{11}$ gładko spuszczanych i sufit takiż pobielany.

[k. 2v] Sytuowany ten kościoł w miasteczku partykularnym Kroszynie o 6 mil od powiatowego miasta Nowogródka odległy, od miasteczek zaś okolicznych najbliższych, w których stacje pocztowe znajdują się - Stwołowicze o milę, od Snowia o mil trzy położony. Od kościołów parafialnych okolicznych oddalony jest od stwołowickiego murowanego na milę 1, od darewskiego drewnianego na milę jedną, swojatyckiego drewnianego mil 2, snowskiego murowanego mil 3, zadwiejskiego drewnianego mil 2, połoneczckiego drewnianego mil dwie. Altaryj, filii ani kaplicy żadnej w obrębie swej parafii nie ma. Kollatorem tego pro-

parafialnych z ramienia KEN. Od 1774 roku usiłował założyć własną drukarnię. W roku następnym doszedł do porozumienia z Antonim Tyzenhauzem i został prefektem drukarni zorganizowanej w Grodnie. Wydawał „Kalendarz Grodzieński” i współredagował „Gazetę Grodzieńską”. Założył i wydawał w latach 1792-1794 „Korespondenta Warszawskiego”, a po 1793 roku „Korespondenta Krajowego i Zagranicznego" (do 1796 roku). Występował przeciw Targowicy. Od 1792 roku był prałatem żmudzkim. Jako eksjezuita interesował się losami zakonu. Por. Encyklopedia wiedzy o jezuitach na ziemiach Polski i Litwy 1564-1995, red. L. Grzebień, Kraków 1996, s. 404.

${ }^{7}$ Kruhlaki - z rosyjskiego kruglak - pnie drzew. Drzewo budowlane, okrągłe bale.

${ }^{8}$ Magnuszewski Wojciech, pleban kroszyński; odbudował kościół parafialny pw. Bożego Ciała w Kroszynie po pożarze świątyni w czasie potopu szwedzkiego. Kościół ten został poświęcony dnia 22 maja 1821 roku przez ks. Jana Walentego Zana, proboszcza w Iszkołdzi.

${ }^{9}$ Figura - tu: kształt, plan.

${ }^{10}$ Balasek (l. mn. balaski) - balustrada z kamiennych balasków.

${ }^{11}$ Tarcica - deski otrzymane z pociętych okrąglaków równolegle do ich osi podłużnych. 
bostwa jest J[aśnie] O[świecony] Książę Konstanty Radziwiłł ${ }^{12}$ - z przykładów pokazuje się, że reperacja kościoła i fundi $i^{13}$ pleban załatwiał.

\section{Opisanie duchownych obligacji}

$\mathrm{Z}$ dawnego zwyczaju w tym kościele, tak z przyczyny tytułu kościoła, jako też $\mathrm{z}$ powszechnego postanowienia jeden tylko fest ${ }^{14}$ na Boże Ciało obchodzi się, na który dosyć liczne zbiera się zgromadzenie. Anniwersarz ${ }^{15}$ dedikacyi 14 niedzieli po [Zielonych] Świątkach dotąd obchodził się prywatnie, dopiero w nowym kościele może się odmienić. Od fundatora kościoła kroszyńskiego żadnej nie ma włożonej obligacji, powodem zaś pobożnej legacyi $2000 \mathrm{z}[\nmid \mathrm{lo} t \mathrm{t}[\mathrm{y}] \mathrm{ch}$ pol[ski]ch, na dobrach Stare Żyrowie zwanych, opartych i ulokowanych, w każdy wtorek Msza Ś[więta] jedna za dusze w czyścu będące odprawuje się. Utrzymywania komendarza z funduszu żadnego obowiązku nie ma; lecz ludność parafii i słabe zdrowie plebana do tego przymusza.

\section{3o Opisanie sprzętow kościelnych}

\begin{tabular}{|c|l|c|}
\hline L.p. & \multicolumn{1}{|c|}{ Apparaty } & Sztuki \\
\hline 1 & $\begin{array}{l}\text { Ornatów białych lamowych z kolumnami w paski materyi angielskiej, galonami } \\
\text { srebrnemi obłożonych starych dwa [dopisane ołówkiem: ... }\end{array}$ & 2 \\
\hline 2 & $\begin{array}{l}\text { Ornat zielony materii chińskiej stary, z kolumną lamową białą, galonem szero- } \\
\text { kim srebrnym obłożony, z stułą, manipularzem, welum i pelką jeden [dopisane } \\
\text { ołówkiem: nie ma] }\end{array}$ & 1 \\
\hline 3 & Ditto zielony, materii chińskiej, z galonem srebrnym, stary, jeden & 1 \\
\hline 4 & $\begin{array}{l}\text { Ornat materyi francuzkiej biały, w kwiaty srebrne, różowe, zielone, grylinowe, } \\
\text { galonem srebrnym obłożony, stary, jeden }\end{array}$ & 1 \\
\hline 5 & $\begin{array}{l}\text { Ornat zielony, aksamitny z kolumną różową w kwiaty, z kompanką srebrną } \\
\text { i kolumną galonem srebrnym obłożoną stary, jeden }\end{array}$ & 1 \\
\hline 6 & $\begin{array}{l}\text { Ornat aksamitny, zielony, z kolumną materyi angielskiej, fioletowy, w paski } \\
\text { i kwiaty różowe, zielone, białe, galonem srebrnym obłożony, stary }\end{array}$ & 1 \\
\hline 7 & $\begin{array}{l}\text { Ornat czerwony, atłasowy, z kolumną kitajkową różową, pasamanami jedwabne- } \\
\text { mi żółtemi obłożony, stary, jeden }\end{array}$ & 1 \\
\hline 8 & $\begin{array}{l}\text { Ornat bardzo stary, niebieski, materii staroświeckiej, w floresy białe i żółtawe, } \\
\text { z kolumną zieloną, galonem srebnym obłożoną, a sam ornat kompanką różową } \\
\text { oszyty jeden }\end{array}$ & 1 \\
\hline
\end{tabular}

${ }^{a}$ Ditto (łac.) - także, podobnie.

${ }^{12}$ Radziwiłł Konstanty Mikołaj (ur. 5 IV 1793 r. w Rzymie (Lazio), zm. 6 IV 1869 r. w Połoneczce) - arystokrata, książę, od 2 września 1800 roku noszący tytuł hrabiego na Szydłowcu (mimo utracenia zwierzchności nad tymi dobrami). Na Litwie znany jako Maciej Konstanty, był synem Macieja i Elżbiety z Chodkiewiczów, córki Jana Mikołaja. W 1815 roku ożenił się z Marią Grabowską, która zmarła w 1826 roku, nie pozostawiając potomstwa. Trzy lata później zawarł związek małżeński z Celestyną z Sulistrowskich. Z tego małżeństwa mieli córkę Jadwigę. W 1840 roku ponownie ożenił się z Adelą Siestrzanek-Karnicką, z którą miał 8 dzieci: 3 córki i 5 synów. www.geni. com/people/Konstanty-Mikołaj-Radziwił/6000000002367834005 (dostęp: 4.10.2016).

${ }^{13}$ Fundi (łac). - fundusze.

${ }^{14}$ Fest (z łac. lub niem.) - święto.

${ }^{15}$ Anniwersarz (łac.) - rocznica. 


\begin{tabular}{|c|c|c|}
\hline $\begin{array}{c}{[\mathbf{k} .} \\
3 \mathbf{3 r}] \\
9\end{array}$ & $\begin{array}{l}\text { Ornat bardzo stary, zielony, z kolumną atłasową karmazynową, pasamanami } \\
\text { szychem tkanemi obłożony, sam zaś ornat frędzelką jedwabną, koloru żółtego, } \\
\text { niebieskiego i zielonego obszyty, cum omnibus requisitis }{ }^{\mathrm{b}} \text {, stary, jeden }\end{array}$ & 1 \\
\hline 10 & $\begin{array}{l}\text { Ornat czerwony na dnie atłasowym z floresami czarnemi, z kolumną różową } \\
\text { kitajkową - pasamanami jedwabnemi obłożony, stary, jeden }\end{array}$ & 1 \\
\hline 11 & $\begin{array}{l}\text { Ornat czarny, aksamitny, z kolumną białą atłasową, z galonem srebrnym, cum } \\
\text { omnibus requisitis, stary, jeden }\end{array}$ & 1 \\
\hline 12 & $\begin{array}{l}\text { Ornat gredyturowy, czarny, z kolumną na dnie białym, w kwiaty różowe, galo- } \\
\text { nem srebrnym obłożony, z stułą i manipularzem, stary, jeden }\end{array}$ & 1 \\
\hline 13 & Ornatów przytem w różnych kolorach cztery & 4 \\
\hline 14 & $\begin{array}{l}\text { Dalmatyk bardzo starych na dnie atłasowem białym w floresy karmazynowe w } \\
\text { poprzek idące, frędzelką iedwabną obłożonych, z dwoma manipularzami, dwie }\end{array}$ & 2 \\
\hline \multicolumn{3}{|c|}{ Kapy } \\
\hline 1 & $\begin{array}{l}\text { Kapa zielona materyi chińskiej, w różne floresy, galonem srebrnym obłożona, } \\
\text { poły kitajką ceglastą, a tył astrachaniem zielonem podszyta, z zapięciem srebr- } \\
\text { nem, jedna }\end{array}$ & 1 \\
\hline 2 & $\begin{array}{l}\text { Kapa zielonego aksamitu z szczytem i lisztwami materialnemi w floresy białe i } \\
\text { zielone, z zapięciem srebrnym, znacznie używana, stara, jedna }\end{array}$ & 1 \\
\hline 3 & $\begin{array}{l}\text { Kapa czarna manszestrowa z szczytem i listwami błękitnemi manszestrowemi } \\
\text { używana iedna [dopisane olówkiem: z srebrnym zapięciem] }\end{array}$ & 1 \\
\hline \multicolumn{3}{|c|}{ Bielizna } \\
\hline 1 & Alb holenderskich i szwabskich z korunkami szerokiemi, starych, cztery & 4 \\
\hline 2 & Alb tkackich, bardzo starych, z korunami szerokiemi & 2 \\
\hline 3 & Alba holenderska, nowa, z korunami szerokiemi & 1 \\
\hline 4 & $\begin{array}{l}\text { Korporałów holenderskich i tkackich, bardzo starych, trzynaście [dopisek } \\
\text { ołówkiem: nowych osiem] }\end{array}$ & 13 \\
\hline 5 & $\begin{array}{l}\text { Puryfikaterzów różnych, mało do użycia zdatnych, dwadziescia [dopisek ołów- } \\
\text { kiem: 30] }\end{array}$ & 20 \\
\hline 6 & Tuwalnia szwabska z koronką siatkową, dobra, jedna & 1 \\
\hline 7 & Tuwalni szwabskich i tkackich, cerowanych i łatanych, trzy & 3 \\
\hline 8 & $\begin{array}{l}\text { Tuwalni perkalowych, z koronami szerokiemi, nowych, z których jedna włócz- } \\
\text { kami w kwiaty szyta, dopiero sporządzonych, pięć }\end{array}$ & 5 \\
\hline 9 & Komża holenderska z koroną szeroką, stara, jedna & 1 \\
\hline 10 & Komż tkackich z koroneczkami, starych, dwie & 2 \\
\hline 11 & Komż szwabskich z koronkami, dobrze używanych, dwie & 2 \\
\hline 12 & Komeżek starych, tkackich, z koroneczkami, pięć & 5 \\
\hline 13 & Obrus tkacki, stary, z korunką, jeden, ditto różnych obrusów cztery ogółem & 5 \\
\hline 14 & Humerałów różnego gatunku, mało zdatnych, jedenascie [dopisek ołówkiem: 12] & 11 \\
\hline 15 & $\begin{array}{l}\text { Ręczników większych, bardzo starych, podartych jedenaście [dopisek ołówkiem: } \\
\text { nowych } 6 \text {, starych } 3,9 \text { ] }\end{array}$ & 11 \\
\hline 16 & Ręczników przy ołtarzach różnego płótna, starych, sześć & 6 \\
\hline \multicolumn{3}{|c|}{ [k. 3v] Różny sprzęt kościelny } \\
\hline 1 & Antepedium na białym dnie, stare, jedne & 1 \\
\hline 2 & Antepedium kałamejkowe, w kwiaty, z bretami kamlotowemi, stare, jedne & 1 \\
\hline
\end{tabular}

${ }^{\mathrm{b}}$ Cum omnibus requisitis (łac.) - z calym wyposażeniem. 


\begin{tabular}{|c|c|c|}
\hline 3 & Antepedium sztametowe, granatowe, stare, jedne & 1 \\
\hline 4 & Kobierzec turecki, używany, jeden & 1 \\
\hline 5 & $\begin{array}{l}\text { Obicia na astrachani granatowej, różnemi kawałkami z materyi jedwabnej wy- } \\
\text { szywane, historię Ś }[\text { więteg]o Jana Nepomocena wyrażające, bardzo starego, } \\
\text { sztuk pięć }\end{array}$ & 5 \\
\hline 6 & Ramy do tabernaculum, jedne & 1 \\
\hline 7 & Całunów czarnych, z krzyżami białemi, dwa & 2 \\
\hline 8 & Bursa bardzo stara, jedna & 1 \\
\hline 9 & Baldachim kitajkowy bardzo stary, jeden [dopisek ołówkiem: nie ma] & 1 \\
\hline 10 & Baldachim z kitajki karmazynowej z frędzlami i galonikiem srebrnym & 1 \\
\hline 11 & Chorągwi kościelnych, bardzo starych, cztery & 4 \\
\hline 12 & Krzyżow processyalnych dwa. Ditto ołtarzowych trzy, ogółem pięć & 5 \\
\hline 13 & Biretów starych trzy [dopisek ołówkiem: biret 1] & 3 \\
\hline 14 & $\begin{array}{l}\text { Pasków włóczkowych starych dwa, jedwabnych starych dwa, niciowy jeden [do- } \\
\text { pisek ołówkiem: nowych 8] }\end{array}$ & 1 \\
\hline 15 & Poduszek na ołtarzu, włóczkowych, starych, dwie & 2 \\
\hline 16 & Poduszka aksamitu zielonego, stara, jedna & 1 \\
\hline 17 & Ampułek szklanych para jedna & 1 \\
\hline 18 & Kanonów z tablicami pięć & 5 \\
\hline 19 & Umbraculum z gazy, w kwiaty, stare, jedne & 1 \\
\hline 20 & Krzesło stare, skórą obite, jedne & 1 \\
\hline 21 & $\begin{array}{l}\text { Szafa w zakrystyi na skład apparatów, z czterma większemi i tyluż mniejszemi } \\
\text { szafami, z gałeczkami mosiężnemi do wysuwania, nowo zrobiona, czerwona, } \\
\text { malowana, na której wierzch mniejszy, stary, odnowiony, z okienkami, sztuka }\end{array}$ & 1 \\
\hline 22 & $\begin{array}{l}\text { Cyborium drewniane, zewnątrz perłowo, z obwódką złotą, a wewnątrz oranżowo } \\
\text { malowane, nowo do wielkiego ołtarza zrobione, jedne }\end{array}$ & 1 \\
\hline 23 & Chrzcielnica stara, odnowiona, jedna & 1 \\
\hline \multicolumn{3}{|c|}{ Ozdoby kościelne idque obrazy } \\
\hline 1 & $\begin{array}{l}\text { Obraz Wieczerzy Pańskiej na płótnie, olejno nowo odmalowany, w ramach drew- } \\
\text { nianych, pozłacanych, na ścianie w wielkim ołtarzu umieszczony, jeden }\end{array}$ & 1 \\
\hline 2 & $\begin{array}{l}\text { Ditto Niepokalanego N[arodzenia] P[anny] Maryi, także na płótnie nowo zrobio- } \\
\text { ny, w ramach drewnianych pozłacanych, w ołtarzu pobocznym prawym umiesz- } \\
\text { czony, jeden }\end{array}$ & 1 \\
\hline 3 & $\begin{array}{l}\text { Ditto Ś[więtego] Mikołaja, nowo na płótnie zrobiony, w takichże ramach, w oł- } \\
\text { tarzu lewym }\end{array}$ & 1 \\
\hline 4 & $\begin{array}{l}\text { Ditto dwa obrazy, jeden Ś[więtego] Dominika Wyznawcy, drugi Ś }[\text { więtego] } \\
\text { Wincentego Fereriusza, oba na płótnie nowo malowane, w ramach drewnianych } \\
\text { czarno malowanych, sztuk }\end{array}$ & 2 \\
\hline $\begin{array}{l}{[\mathbf{k} .} \\
4 \mathbf{r}] \\
5\end{array}$ & $\begin{array}{l}\text { Obraz drugi Niepokalanego Poczęcia NMP na płótnie, stary, odnowiony, w ram- } \\
\text { kach drewnianych, jak i dwa poprzedzaiące na ścianie umieszczony jeden }\end{array}$ & 1 \\
\hline 6 & $\begin{array}{l}\text { Ditto 2-gi Ś[więteg]o Mikołaja, stary, odnowiony, w ramkach na ścianie w ko- } \\
\text { ściele także umieszczony }\end{array}$ & 1 \\
\hline 7 & $\begin{array}{l}\text { Cztery figury drewniane rżnięte, olejno biało malowane SS.[= Świętych] Piotra } \\
\text { i Pawła apostołów, Ignacego Lojoli, Ś[więteg]o Antoniego, lekkie, na ścianach } \\
\text { przybite }\end{array}$ & 4 \\
\hline
\end{tabular}




\begin{tabular}{|c|c|c|}
\hline 8 & $\begin{array}{l}\text { Ławki i konfesjonały nowo sporządzone, w ogólnym opisaniu kościoła wyżej } \\
\text { są umieszczone, nadto kilka sztuk starych drewnianych sprzętów w szopie starej } \\
\text { znajduią się }\end{array}$ & \\
\hline 9 & $\begin{array}{l}\text { W prezbitorium }[s] \text { na suficie } \mathrm{z} \text { tarcic obraz stworzenia świata, czyli oddzielenia } \\
\text { światła od ciemności, a na ścianach tegoż prezbitorium }[s] \text { nisko, prócz inszego } \\
\text { malowidła dwa wyobrażające mękę i zdradzenie Chrystusa Pana }\end{array}$ & 3 \\
\hline L.p. & $4^{\text {to }}$ Opisanie zlota, srebra i dalszych metalów & Sztuki \\
\hline 1 & Monstrancja nowa srebrna z podwójnemi promieniami cała pozłacana jedna & 1 \\
\hline 2 & Kielichów wewnątrz i zewnątrz pozłacanych dwa & 2 \\
\hline 3 & Ditto srebrny, wewnątrz tylko pozłacany, jeden & 1 \\
\hline 4 & $\begin{array}{l}\text { Paten srebrnych zupełnie pozłoconych trzy. Ditto srebrna wewnątrz tylko zło- } \\
\text { cona, jedna }\end{array}$ & 4 \\
\hline 5 & Puszka srebrna w środku tylko pozłacana, jedna & 1 \\
\hline 6 & $\begin{array}{l}\text { Vasculum pro portando viatico, czyli patena z nakrywką dla noszenia Komunii } \\
\text { dla chorych, srebrna, jedna }\end{array}$ & 1 \\
\hline 7 & Krzyż srebrny z passyjką, jeden & 1 \\
\hline 8 & Obrączka złota jedna, ditto srebrna pozłacana, jedna, ogółem dwie & 2 \\
\hline 9 & [dopisane ołówkiem: Pacyfikał miedziany wyzłacany z relikwiami jeden] & 1 \\
\hline \multicolumn{3}{|c|}{ Metal } \\
\hline 1 & $\begin{array}{l}\text { Lichtarzów cynowych wielkich dwanaście. Ditto mniejszych sześć, malękich [s] } \\
\text { dwa }\end{array}$ & 20 \\
\hline 2 & Tacka cynowa do ampułek jedna. Ampułek takichże para jedna, ogół sztuk & 3 \\
\hline 3 & Vasculów cynowych do SS [= Świętych] Olejów, dwoje & 2 \\
\hline 4 & Puszka na sól święcona, jedna & 1 \\
\hline 5 & Kropielniczka cynowa, jedna & 1 \\
\hline 6 & Kubek cynowy w zakrystii do noszenia wody, jeden & 1 \\
\hline 7 & Łódka cynowa do kadzidła jedna & 1 \\
\hline 8 & [dopisane olówkiem: Miednica cynowa na wodę chrzestną] & 1 \\
\hline 9 & Trybularz ${ }^{\mathrm{a}}$ mosiężny, jeden & 1 \\
\hline 10 & Kociołek mosiężny do wody święconej, jeden & 1 \\
\hline 11 & Żelazo do pieczenia opłatków & 1 \\
\hline 12 & Cyrkuł żelazny do wyrzynania komunikantów & 1 \\
\hline 13 & Szczypce żelazne stare, jedne & 1 \\
\hline 14 & Nożyczki stare, jedne & 1 \\
\hline 15 & Puszka blaszana do hostii, jedna & 1 \\
\hline 16 & Dzwonek wiszący przy zakrystii jeden, przy ołtarzach 4, przy bursie 1 & 6 \\
\hline 17 & Bisiorów sznurków cztery & 4 \\
\hline 18 & $\begin{array}{l}\text { Dzwonów w dzwonicy na cmętarzu [s] stojącej, starej, o czterech słupach drew- } \\
\text { nianych zbudowanej, dranicami krytej, różnej wielkosci spiżowych, cztery }\end{array}$ & 4 \\
\hline 19 & $\begin{array}{l}\text { Ołtarzyk NMP, za processją noszący się, dopiero odnowiony, z firankami jedwab- } \\
\text { nemi, kilku sznurkami, paciorek i dalszemi drobnemi dekoracjami }\end{array}$ & 1 \\
\hline
\end{tabular}

a Trybularz - współcześnie kadzielnica służąca do okadzania w czasie liturgii. Naczynie metalowe na łańcuszkach, zamykane przykrywką, w którym znajdują się rozżarzone węgle, a te posypuje się ziarenkami kadzidła a następnie okadza prowadzący liturgię: ołtarz, dary ofiarne, Najświętszy Sakrament, Ewangeliarz, krzyż, uczestników liturgii . 


\section{[k. 4v] $5^{\text {to }}$ Opisanie funduszu nieruchomego}

Wyszedłszy z cmentarza na drogę do miasteczka prowadzącą, z obu stron parkanem dobrym $z$ drzewa wygrodzoną, po prawej stronie do rezydencji plebańskiej jest brama sztakietowa podwójna, z furtką przy niej takąż, pod daszkiem gątem krytym, z orłem drewnianym na wierzchu, zamczysta i niestara. Przez którą wszedłszy na dziedziniec, a udając się w prawą rękę, niedaleko są dwa swirny ${ }^{16}$ słomą kryte, z drzewa czesanego zbudowane, stare, prawie walące się. Drzwi do nich na zawiasach z zaszczepkami i probojami żelaznemi. Od tych swirnów nieco dalej $\mathrm{w}$ dziedziniec postąpiwszy, dom mieszkalny plebański, dawny, z drzewa zbudowany, słomą niedawno nakryty, w niektórych miejscach podmurowany. Budynek ten jest figury prostokątnej, z ganeczkiem czyli przedsionkiem z cegieł murowanym od frontu, wewnątrz którego ciepła sień na dwoje podzielona, na obie strony onych, naprzód dwa pokoje mieszkalne duże, po trzy okna dwufurtkowe sześcioszybowe z szkła czystego - po jednym piecu z kafel zielonych polewanych z zupełnym przy nich oporządzeniem fizycznym, oraz posadzkę i stolowanie $\mathrm{z}$ tarcic nowych gładkich mające, niemniej drzwi tarciczne gładkie i zamczyste, $\mathrm{w}$ każdym $\mathrm{z}$ nich znajduią się - $\mathrm{z}$ drugiej sieni za przepierzeniem murowanym po obu stronach znayduią się dwie stancyjki mniejsze mieszkalne, piecami z pierwszych dwóch pokojów ogrzewane - po jednym oknie jak i pierwsze dwufurtkowym, zupełnie okutem, mające stolowanie w obydwu tarciczne na belkach, posadzka w jednym tarciczna, w drugim ceglana - z tyłu domu dla utrzymania ciepła w sieniach piec mających - przebudowany, drugi przedsionek z drzewa czesanego z okienkiem i drzwiami zamczystemi. Cały ten budynek wewnątrz gładko gliną pod tarkę wytynkowany i wybielony. Okna i drzwi wszystkie tarciczne, gładko oszalowane i od frontu wszystkie okienice maiące. Za tym domem iest niewielki ogród, w którym prócz dwóch lip dużych i kilku czarnośliwów żadnego drzewa fruktowego nie ma. Od frontu tego domu przechodząc dziedziniec, w środku jest studnia z żurawiem, której zrąb nowy - za nią budynek folwarkowy, z drzewa czesanego postawiony, dranicami ${ }^{17}$ niedawno nakryty, w którym piekarnia dla czeladzi. Izba dla ekonoma i kuchnia murowana w sieniach znajdują się. Okien kilka dużych z szkła drobniejszego, lecz czystego - w tyle tego budynku ogród warzywny, w którym browar stary, dranicami kryty i przy nim nowym dopiero zaczęty - przy browarze są dwie studnie niestare. Za sadzawką słodownia porządna, nowo postawiona, dranicami kryta, wewnątrz doskonale rozporządzona. Niedaleko ku wschodowi słońca obora stara, słomą kryta, z kilku przedziałami, o dwóch wrotach dranicznych większych i trojga tarcicznych drzwiach mniejszych w nieodległości. Druga obora bokiem do pierwszej, a frontem do południa stojąca, z kruhlaków zbudowana, słomą kryta, także stara o dwojgu wrotach tarcicznych dużych, do zapędzenia stada. Na przedzie której ptasznik ${ }^{18} \mathrm{z}$ drzewa

${ }^{16}$ Świren, świron, świernia - spichlerz litewski na zboże, a zwłaszcza lamus, skarbiec, spiżarnia w oddzielnym budynku.

${ }^{17}$ Dranica - cienka, wąska deska łupana z pnia drzewa iglastego, używana w budownictwie drewnianym, stosowana głównie do krycia dachów.

${ }^{18}$ Ptasznik - w obrębie gospodarstwa, na grubym słupie (palu) umieszczona buda z odpowiednimi otworami (wejściami) ze wszystkich stron dla gołębi hodowanych w gospodarstwie lub dla ptaków dla ich podkarmiania. 
brusowego ${ }^{19} \mathrm{w}$ winkiel zbudowany, gątami w jedną stronę pochyło kryty, [k. 5, r] z czworga drzwiami tarcicznemi na zawiasach i krukach żelaznych z kilku szklannemi okienkami, nowy. Obok tego w równej linii z drzewa brusowego zbudowana, słomą pokryta stajnia $\mathrm{i}$ wozownia, $\mathrm{z}$ tych stajnia na dwie części podzielona, z kilku przeorynami z tarcic dylówek, a tak w stajniach, jako i wozowni podłoga $\mathrm{z}$ tarcic. Drzwi tarcicznych od frontu troje, a czwarte $\mathrm{z}$ tyłu, wszystkie podwójne na zawiasach i krukach żelaznych; ten budynek nowy, dalej ku wschodowi idąc w tejże dyrekcyi niżej trochę od stajni, z drzewa brusowego nowo przesypany, słomą kryty, o trojgu drzwiach tarcicznych na zawiasach i krukach żelaznych ptasznik drugi. Dalej w kierunku równiejszym za stajnią spichrz nowy, z drzewa brusowego sklutowanego zbudowany, na podmurowaniu, z kolumnadą od frontu wzdłuż drewnianą, gątami kryty, na trzy części wewnątrz podzielony, do każdego z tych z podwórza są drzwi tarciczne pojedyncze, duże, zamczyste, na zawiasach i krukach żelaznych, wewnątrz każdego podłoga i stolowanie $\mathrm{z}$ tarcic $-\mathrm{z}$ jednego z których wschody na górę do składu różnego dobrze urządzoną, a tak w każdym oddziale spichrza, jako też i na górze są okna szklanne duże, a niektóre z nich $\mathrm{z}$ kratą drewnianą. Dalej na wschód dwa gumna ${ }^{20}$ nowe, duże, z drzewa okrągłego niedawno zbudowane, słomą nakryte, na skład krescencji z tokami do młócenia z kilkoro wrotami tarcicznemi zamczystemi, a trzecie gumno w pośrodku tych innym frontem stojące, także z drzewa okrągłego zbudowane, słomą nakryte, stare. Tuż przy tych gumnach na prawo swironek z drzewa okrągłego, słomą kryty, z drzwiczkami poiedynczemi tarcicznemi, stary, niedaleko w ogródku wyżej wyrażonym znajduje się kurnik - stary, z drzewa okrągłego zbudowany, słomą pochyło w iedną stronę jak pierwszy ptasznik nakryty, z kilku małemi okienkami szklannemi. W tymże ogródku bliżej budynku mieszkalnego lodownia z drzewa brusowego nowo postawiona, słomą pokryta, okien dużych szklannych trzy i drzwi tarciczne pojedyncze zamczyste na zawiasach i krukach żelaznych maiąca. Oraz sklep na skład lodu, czyli zrąb drewniany porządny, podłoga i stolowanie $\mathrm{z}$ tarcic. Cała ta plebania nad rzeką tu jeszcze niespławną Szczarą położona, parkanem porządnie z drzewa w koło ogrodzona, a wszelka tak naprawiona, jako i nowa budowla jest kosztem teraźniejszego plebana wzniesiona; który wiele w niej zrobił reformy, przeświadcza porównanie Inwentarza podawczego w 1810 roku sporządzonego, z niniejszą wizytą, gdzie powiedziano, że całe zabudowanie plebanii w długim pożyciu przez władnącego nią poprzednika nie tylko w całości, lecz i w części nie będąc nigdy poprawiane, dawnością czasu opustoszałe i zrujnowane zostało, z dzisiejszej zaś wizyty przekonać się można, że każda budowla między pierwszemi w swoim rzędzie liczyć może, i powinna.

\footnotetext{
${ }^{19}$ Brus - grube, z lekka opiłowane drzewo budulcowe.

${ }^{20}$ Gumno - budynek, w którym składa się zboże przed wymłóceniem, stodoła.
} 


\section{[k. 5v] Różny sprzęt funduszowy plebanii kroszyńskiej inwentarzem podaw- czym w roku 1810 obięty i do zostawienia przy ekspiracyi należny}

\begin{tabular}{|c|c|c|}
\hline L.p. & Cyna, miedź i żelazo & Sztuki \\
\hline 1 & Misa cynowa $\mathrm{z}$ antabami ${ }^{\mathrm{a}}$, jedna & 1 \\
\hline 2 & Półmisków sześć & 6 \\
\hline 3 & Talerzy pięć & 5 \\
\hline 4 & Łyżek cynowych & 3 \\
\hline 5 & Nożów dwa w cynę, a trzeci w kość oprawnych, starych & 3 \\
\hline 6 & Kocioł browarny mały, stary, lat kilkanaście mający & 1 \\
\hline 7 & Trąb i przytrąbków miedzianych trzy, cała ta miedź waży funtow 54 & 3 \\
\hline 8 & Sklut niewielki, stary, jeden & 1 \\
\hline 9 & Piła poprzeczna, bardzo stara, do użycia niezdatna, jedna & 1 \\
\hline 10 & Świder stary jeden & 1 \\
\hline 11 & Dłuto małe, stare, jedno & 1 \\
\hline 12 & Skowroda dziurawa bez rączki, jedna & 1 \\
\hline 13 & Garniec blaszany, stary, zepsuty, jeden & 1 \\
\hline 14 & Nóż kuchenny, niezdatny do niczego, jeden & 1 \\
\hline \multicolumn{3}{|c|}{ Naczynia drewniane gospodarskie } \\
\hline 1 & $\begin{array}{l}\text { Czopów do zatoru, starych, z dnami wypaczonemi, dwa, a trzeci zbyt stary na } \\
\text { brachę }\end{array}$ & 2 \\
\hline 2 & Kadzi brażnych, starych, dwie & 2 \\
\hline 3 & Łahun stary jeden & 1 \\
\hline 4 & Cebrów starych cztery & 4 \\
\hline 5 & Beczek piwnych, starych, ośm & 8 \\
\hline 6 & Kufa stara od garcy, stara, jedna & 1 \\
\hline 7 & Trąbniczka stara od alembiku, jedna & 1 \\
\hline 8 & Trąbnica większa, stara, popsuta, jedna & 1 \\
\hline 9 & Koryt piwnych małych, starych, dwa & 2 \\
\hline 10 & Kadzi warzywnych, starych, trzy & 3 \\
\hline 11 & Dzież chlebnych, dwie & 2 \\
\hline 12 & Newłek starych, dwoje & 2 \\
\hline 13 & Wiadro stare jedne & 1 \\
\hline 14 & Mis drewnianych, starych, dwie & 2 \\
\hline 15 & Przeszot starych, dwa & 2 \\
\hline 16 & Koryt piekarnianych, starych, trzy & 3 \\
\hline 17 & Ośmin do mierzenia zboża, dwie & 2 \\
\hline 18 & Fas na zboże starych & 4 \\
\hline 19 & Stołów wszystkich, sześć & 6 \\
\hline 20 & Stołków sztuk dziesięć & 10 \\
\hline 21 & $\begin{array}{l}\text { Stoły i stołki z drzewa sosnowego roboty ordynaryjnyj, stare, mało do użycia zdat- } \\
\text { ne }\end{array}$ & \\
\hline 22 & Sito stare, dziurawe, łatane, jedne & 1 \\
\hline
\end{tabular}

${ }^{a}$ Antaba - (metalowy) uchwyt. 


\section{Specyfikacja rzeczy różnego rodzaiu przez sukcesorów zeszlego ks[ię]dza [Karola] Malinowskiego do inwentarza funduszowego zostawionych i po- daniem objętych}

Płótna zgrzebnego łokci dwadzieście trzy, wełny run dwadzieście sześć, od funtów dwudziestu pięciu, żyta w ziarnie beczek dwie, ośmina jedna garcy dwa, jęczmienia ośmin dwie, garcy dziewięć i kwarta, gryki beczka jedna, ośmin cztery, pszenicy ośmin trzy, garcy sześć, owsa ośmin sześć, soli garcy dziesięć, krup jęczmięnnych ośmina jedna, mąki żytniej ośmin dwie, wódki garcy siedmdziesiąt sześć, pszczół ul jeden, żyta w snopie kop piędziesiąt i snopów czterdzieście, jęczmienia kop trzynaście, snopów dwadzieście.

\section{Żywioły na inwentarz zostawione}

Koń stary od lat 20 jeden, krów ośm po lat kilkanaście, jedna tylko lat pięć mająca, cieląt przy nich jeszcze nieodstojonych sztuk pięć, ciełuszek dwulatek sztuk trzy, ciełuszek jednolatek sztuk cztery, byczków jednolatków sztuk cztery, byczków po dwa i trzy lata mających sztuk sześć, buhaj czteroletni jeden. Wszystkiego bydła w ogół sztuk trzydzieście dwie, gatunek bydła ordynaryjnego małego, owiec, macior starych dwie, świń macior młodych i starych sztuk dziesięć, wieprzów po lat trzy sztuk trzy, wieprzów roczniaków [k. 6r] i dwulatków sztuk pięć, kiernoz jeden od lat trzech, drugi od lat dwóch. Wszystkich sztuk dwadzieście z gatunku ordynaryjnego prostego. Gęsi sztuk dziesięć, kur sztuk dziesięć, jędyków, sztuk trzy.

\section{6o Opisanie gruntów plebańskich}

Folwarku żadnego oddzielnego prócz plebańskiego zabudowania fundusz kroszyński nie miał i nie ma, placów prócz jednego fundatora na szpital nadanego w miasteczku Kroszynie plebania nie possyduje. Juryzdyczanie zaś przez proboszczów mają sobie wydzielone place od gruntu funduszem do plebanii nadanego, którego tuż przy plebanii podług nadania znajduje się włók ${ }^{21}$ cztery, prócz tych wraz za miasteczkiem Kroszynem o trzy sznury geometryczne idąc ku zachodowi zaczynają się grunta do plebanii kroszyńskiej należne, które są w jednym obrębie i granicach niekwestionowanych. Gruntów takowych podług wymiaru geometrycznego i umyślnie na to sporządzonej mapy plebania kroszyńska posiada włók pięćdziesiąt sześć, morgów dwadzieście cztery, prętów ośm, które graniczą od północy rzeką Szczarą, od wschodu naprzód z gruntami kroszyńskimi przez pół mili, potem z gruntami J[aśnie] W[ielmożneg]o Marszałka Rdułtowskiego ${ }^{22}$ do folwarku Odachowszczyzny należnemi, dalej z gruntami Dubowskiemi kanoni-

${ }^{21}$ Włóka - dawna jednostka powierzchni gruntu ornego równa 30 morgom, czyli 16,8 hektarów. Także grunt o takiej powierzchni.

${ }^{22}$ Ród Rdułtowskich herbu Drogosław był jednym z najpotężniejszych i najbogatszych familii szlacheckich na Kresach Rzeczypospolitej. Rdułtowscy pochodzili z ziemi kujawskiej, a na Litwie i Białej Rusi zamieszkali dopiero w XVI stuleciu. Zasłużeni dla Rzeczpospolitej uzyskiwali od królów polskich wysokie i odpowiedzialne stanowiska i rozległe włości. W 1639 roku rezydencją Rdułtowskich stało się miasteczko Snów koło Nieświeża. Za protoplastę snowskiej linii rodu uważa się Jana Rdułtowskiego (1665-1744). 
ków regularnych słonimskich ${ }^{23}$ i plebanii darewskiej do Kopca narożnego. Dalej idąc ku zachodowi graniczy z gruntami do Kołpienicy Seminaryjskiej należącemi, aż do Kopca drugiego narożnego, od tego Kopca na północ graniczy takoż z gruntami kołpienickiemi, w końcu z gruntami W. Ancuty, wpierając w Szczarę, z której wzięly początek.

Młynu plebania nie ma żadnego, lecz wedle funduszu ma wolne mliwo, bez miarki we młynie dworu kroszyńskiego - oraz wolny ma wstęp łowienia ryb w stawie i w rzece Szczarze do dworu należnych.

Gaju sosnowego, do budowli zdatnego, za wsią plebańską Skarczewem w jednym obrębie ma fundusz kroszyński włok dziewięć niespełna i to w liczbie włók polowych.

\begin{tabular}{|l|c|c|}
\hline \multicolumn{1}{|c|}{ Ilość wysiewu zboża na gruntach plebańskich } & Bek & garcy \\
\hline Żyta beczek dwadziescia, ośmin sześć, garcy siedm & $20 \%$ & 7 \\
\hline Pszenicy ozimej bek dwie, ośmin dwie, garcy ośm & $12 / 8$ & 8 \\
\hline Ditto jarej ośmin pięć & $5 / 8$ &, \\
\hline Jęczmienia bek sześć, ośmin dwie, garcy pięć & $62 / 8$ & 5 \\
\hline Owsa bek jedenaście, ośmin siedm, garcy czternaście & $11_{8}^{7 / 8}$ & 14 \\
\hline Grochu ośmin trzy & $3 / 8$ &, \\
\hline Bobu półtory ośminy & $1 / 8$ & 9 \\
\hline Lnu dwie ośminy i pół & $2 / 8$ & 9 \\
\hline
\end{tabular}

Sianożęci różnego gatunku morożnej i błotnej włók siedm i pół - i to w liczbie pięciudziesiąt sześciu włók polowych.

\section{[k. 6v] Inwentarz ludności juryzdyczan plebańskich w Kroszynie}

1. Marcin Orłowski (lat 34), żona Helena (25), syn Jan (10).

2. Jan Orłowski (23), żona Agata (28), syn Jerzy (3), 2-gi Kazimierz (1), brat Józef (30).

3. Marcin Siergiel (23), żona Marianna (20), brat Jerzy (35), żona Anna (28).

4. Piotr Jelecki (30), żona Katarzyna (25), syn Jan (10), córki 3: Anna (16), Karolina (12), Teofila (3).

Kazimierz Rdułtowski herbu Drogosław (1785-1855) - jedna z najwybitniejszych postaci w rodzie. Był synem Chryzostoma herbu Drogosław (ur. 1750). Dzieciństwo i młodość spędził w Anglii. Uzyskał tytuł doktora filozofii uniwersytetu w Oksfordzie. Poślubił przyrodnią siostrę Teresę. Po powrocie zajął się gospodarowaniem. Założył fabrykę sukna. Pełnił urząd marszałka szlachty nowogródzkiej, był także kawalerem maltańskim. W roku 1810 towarzyszył księciu Druckiemu-Lubeckiemu w delegacji do cara Aleksandra I, a dwa lata później, jako prezydent Komisji WojskowoCywilnej, podejmował w Snowie brata Napoleona, Hieronima Bonaparte. Rdułtowski Kazimierz. http://polesie.org/2036/o-dawnych-wlascicielach-juszkiewicz-czernichowa-adachowszczyzny/ (dostęp: 4.10. 2016).

${ }^{23}$ Kanonicy regularni, kanonicy regularni laterańscy - najstarszy zakon klerycki, zorganizowany w 1105 roku według reguły św. Augustyna. W Słonimie ich klasztor ufundowany został w 1650 roku. W latach 18041832 utrzymywali również szkoły publiczne. Zakon został zniesiony w 1845 roku. 


\section{Powinność tychże juryzdyczan}

Pomienieni wyżej juryzdyczanie w lecie do żniwa po dni dziewięć służą, $\mathrm{z}$ listami, a mianowicie z kursorią posyłani bywają, z gruntu od poletków skarbowych przez plebanów pozwolonego i do użytku im postąpionego trzeci snop dają, albo w miarę jego wartości za dobrowolnym układem i ugodzeniem się czynsz płacą.

\begin{tabular}{|c|c|c|c|c|c|}
\hline \multirow{2}{*}{ Dymy } & \multicolumn{2}{|c|}{ Grunta } & \multirow{2}{*}{$\begin{array}{c}\text { Inwentarz ludności, dymów i uprzęży wsi } \\
\text { plebańskiej Skarczewa }\end{array}$} & \multicolumn{2}{|c|}{ Uprzęż } \\
\hline & wlóki & ćwierci & & konie & woły \\
\hline 1 & $"$ & 2 & $\begin{array}{l}\text { Amielian Krućko (lat 40), żona Audocja (40), pa- } \\
\text { synki: Tomasz (18), Janko (13), Ławryn (9) }\end{array}$ & 1 & 2 \\
\hline 2 & $"$ & 2 & $\begin{array}{l}\text { Ihnat Krućko (28), żona Marysia (26), syn Pauluk } \\
\text { (4) }\end{array}$ & $"$ & 4 \\
\hline 3 & $"$ & 2 & $\begin{array}{l}\text { Harasim Kobiak (46), żona Maryna (40), syn Jan- } \\
\text { ko (6), pasynek Pauluk (19) }\end{array}$ & 1 & 4 \\
\hline 4 & $"$ & 2 & $\begin{array}{l}\text { Chwiedor Krućko (37), żona Hanusia (40), syn } \\
\text { Dziemian (12), Wasil (9) }\end{array}$ & $"$ & 2 \\
\hline 5 & $"$ & 2 & $\begin{array}{l}\text { Ihnat Kobiak (30), żona Katarzyna (22), syn Ro- } \\
\text { man (1), brat Chwiedor (18) }\end{array}$ & $"$ & 4 \\
\hline 6 & $"$ & 2 & $\begin{array}{l}\text { Andrej Kobiak (50), żona Chwiedora (40), syn } \\
\text { Amielian (14), Ihnat (4) }\end{array}$ & $"$ & 1 \\
\hline 7 & $"$ & 3 & $\begin{array}{l}\text { Roman Krućko (60), żona Ahapa (50), syn Sy- } \\
\text { mon (24), Chwiedor (13), Hryczko (7) }\end{array}$ & 1 & 4 \\
\hline 8 & 1 & $"$ & $\begin{array}{l}\text { Jan Krućko (70), żona Ahapa (60), synów 4: Cy- } \\
\text { pruś (22), Chwiedor (16), Amielian (12), Łukasz } \\
\text { (30), żona Katarzyna (23), synów 2: Michał (10) } \\
\text { Sylwester (5) }\end{array}$ & 1 & 4 \\
\hline 9 & $"$ & 2 & $\begin{array}{l}\text { Siemion Krućko (48), żona Marianna (38), córka } \\
\text { Hanula (19), zięć Symon (28) }\end{array}$ & $"$ & 3 \\
\hline 10 & $"$ & 2 & $\begin{array}{l}\text { Zmitruk Leusz (36), żona Zofia (31), pasiorzby } \\
\text { Benedyś (12), Roman (8), Jan (3) }\end{array}$ & $"$ & 2 \\
\hline 11 & $"$ & 2 & $\begin{array}{l}\text { Mikołaj Krućko (25), żona Audocja (26), syno- } \\
\text { wiec Sciepan (5) }\end{array}$ & $"$ & 2 \\
\hline 12 & $"$ & 2 & $\begin{array}{l}\text { Samuś Krućko (40), żona Marianna (28), syn } \\
\text { Janko (13), Hryszko (8) }\end{array}$ & $"$ & 2 \\
\hline 13 & $"$ & 2 & $\begin{array}{l}\text { Maksim Bordzy (30), żona Chwiedora (29), syn } \\
\text { Bazyl (15), Andrej (10) }\end{array}$ & $"$ & 2 \\
\hline 14 & $"$ & 2 & $\begin{array}{l}\text { Ihnat Siergiel (38), żona Eudocja (25), syn Tra- } \\
\text { chim (11), brataniec Jakow (10) }\end{array}$ & $"$ & 2 \\
\hline 15 & $"$ & 2 & $\begin{array}{l}\text { Cypryś Siergiel (40), żona Marianna (36), synów } \\
\text { 4: Pauluk (15), Symon (13), Janko (10), Chwie- } \\
\text { dor (8) }\end{array}$ & 1 & 2 \\
\hline 16 & $"$ & 2 & $\begin{array}{l}\text { Aleksiej Siergiel (40), żona Katarzyna (38), syn } \\
\text { Pauluk (20), Janko (13) }\end{array}$ & 1 & 4 \\
\hline 17 & $"$ & 2 & $\begin{array}{l}\text { Tomasz Nieczaj (26), żona Agata (24), syn Jan, } \\
\text { (4) Andrzej (1) }\end{array}$ & $"$ & 2 \\
\hline
\end{tabular}




\begin{tabular}{|c|c|c|c|c|c|}
\hline 18 & ” & 2 & $\begin{array}{l}\text { Chwiedor Krućko (54), żona Nastusia (50), syn } \\
\text { Harasim (20), Hryszko (16) }\end{array}$ & " & 4 \\
\hline 19 & ” & 2 & $\begin{array}{l}\text { Sciepan Kobiak (30), żona Dorota (25), syn Ga- } \\
\text { briel (7), Hryszko (1) }\end{array}$ & 1 & 3 \\
\hline 20 & , & 2 & Zmitruk Kobiak (40), żona Magdalena (39) & , & 2 \\
\hline $\begin{array}{l}{[k .7 r]} \\
21\end{array}$ & ” & 2 & $\begin{array}{l}\text { Jan Wołyniec (40), żona Marianna (30), syn } \\
\text { Eliasz (8) }\end{array}$ & ” & 3 \\
\hline 22 & ” & 2 & $\begin{array}{l}\text { Sylwester Siergiel (42), żona Marianna (45), bra- } \\
\text { taniec Siemion (20) }\end{array}$ & 1 & 3 \\
\hline 23 & ” & 2 & $\begin{array}{l}\text { Tomasz Kobiak (33), żona Cecylia (20), syn Jó- } \\
\text { zef (5) }\end{array}$ & ” & 2 \\
\hline 24 & ” & 2 & $\begin{array}{l}\text { Tomasz Leusz (34), żona Parasia (30), syn Tra- } \\
\text { chim (16) }\end{array}$ & ” & 3 \\
\hline 25 & ” & 2 & $\begin{array}{l}\text { Jan Leusz (54), żona Chwiedora (60), syn An- } \\
\text { drzej (20) }\end{array}$ & ” & 2 \\
\hline 26 & ” & 2 & $\begin{array}{l}\text { Hryszko Lickiewicz (41), żona Zosia (30), syn } \\
\text { Taras (12) }\end{array}$ & 1 & 3 \\
\hline 27 & ” & 2 & $\begin{array}{l}\text { Jakow Krućko (50), żona Aksienia (50), syn Ja- } \\
\text { kim (16), Winceś (12), Ławryn (9) }\end{array}$ & ” & 2 \\
\hline 28 & ” & 2 & $\begin{array}{l}\text { Lawryn Krućko (40), żona Parasia (30), syn } \\
\text { Hryszko (15), Teodor (3) }\end{array}$ & ” & 2 \\
\hline 29 & " & 2 & $\begin{array}{l}\text { Szczepan Kobiak (32), żona Tacjana (26), syn } \\
\text { Janko (4), Symon (1) }\end{array}$ & 1 & 2 \\
\hline 30 & ” & 2 & $\begin{array}{l}\text { Pauluk Wojtowicz (45), żona Auksenia (40), sy- } \\
\text { nów 4-ch: Szczepan (15), Siemion (14), Jan (6), } \\
\text { Mikołaj (3) }\end{array}$ & ” & 2 \\
\hline 31 & ” & 2 & $\begin{array}{l}\text { Józef Leusz (34), żona Aksienia (40), synów } \\
\text { trzech: Sylwester (9), Franciś (5), Kazimierz (2) }\end{array}$ & " & 4 \\
\hline 32 & " & 2 & $\begin{array}{l}\text { Chwiedor Lickiewicz (36), żona Dorota (33), } \\
\text { brat Józef (33), żona Marysia (25), synów 2-ch:- } \\
\text { Amielian (3), Aleksiej (2) }\end{array}$ & ” & 4 \\
\hline 33 & , & 2 & Eliasz Kalinowski (23), brat Szczepan & , & , \\
\hline 34 & ” & 2 & $\begin{array}{l}\text { Michałko Jelecki (30), żona Elżbieta, brat Alek- } \\
\text { siej, żona Hanusia, syn Janko }\end{array}$ & 2 & 3 \\
\hline 35 & , & 2 & Daniło Kalinowski (24), żona Chwiedora (25) & , & 4 \\
\hline 36 & " & 2 & $\begin{array}{l}\text { Szczepan Jelecki (50), żona Marysia (46), synów } \\
\text { 5-ciu: Janko (18), Wasil (13), Siemion (9), Ga- } \\
\text { bruś (7), Daniło (4) }\end{array}$ & 1 & 5 \\
\hline 37 & ” & 2 & $\begin{array}{l}\text { Siemion Borzdy (50), żona Marianna, syn Hrysz- } \\
\text { ko (13), Józef (10) }\end{array}$ & 1 & 3 \\
\hline 38 & ” & 2 & $\begin{array}{l}\text { Onufry Wołyniec (34), żona Teresa (24), synów } \\
\text { 2-ch: Taras ( } 7) \text {, Janko (4), brat Chwiedor (24), } \\
\text { żona Marianna (20) }\end{array}$ & 1 & 2 \\
\hline 39 & \# & 2 & Samuś Jelecki (54), syn Kazimierz (30) & 1 & 3 \\
\hline 40 & ” & 2 & $\begin{array}{l}\text { Bazyl Leusz (70), syn Wasil (32), Hryszko (18), } \\
\text { Symon (15), Roman (9) }\end{array}$ & 1 & 3 \\
\hline
\end{tabular}




\begin{tabular}{|c|c|c|c|c|c|}
\hline & " & ", & $\begin{array}{l}\text { Janko Siergiel (50), żona Hanusia (45), syn To- } \\
\text { masz (28), Kondrat (15), Hryszko (5) }\end{array}$ & " & " \\
\hline 41 & " & 2 & $\begin{array}{l}\text { Symon Tomaszuk (29), żona Audocia (20), syn } \\
\text { Mikołaj (3) }\end{array}$ & 1 & 4 \\
\hline 42 & " & 2 & $\begin{array}{l}\text { Szczepan Kobiak (40), syn Dziemian (10), Sy- } \\
\text { mon (7), brat Sebestian (30) }\end{array}$ & " & 4 \\
\hline 43 & " & 2 & $\begin{array}{l}\text { Pilip Krućko (40), żona Teresa (30), syn Siemion } \\
\text { (19), Chwiedor (3) }\end{array}$ & $"$ & 3 \\
\hline 44 & " & 2 & $\begin{array}{l}\text { Wasil Jelecki (60), żona Marianna (45), zięć Onu- } \\
\text { fry ( } 28)\end{array}$ & 1 & 3 \\
\hline 45 & $"$ & 2 & $\begin{array}{l}\text { Marcin Siergiel (40), żona Marianna (30), brat } \\
\text { Mikołaj (50), żona Hanusia (30), synowie Kon- } \\
\text { drat (12), Maciej (8), Ihnat (5) }\end{array}$ & $"$ & 4 \\
\hline 46 & $"$ & 2 & $\begin{array}{l}\text { Adam Siergiel (40), żona Tekla (30), syny: Jakow } \\
\text { (12), Joachim (10), Daniło (5), Hryszko (1) }\end{array}$ & $"$ & 4 \\
\hline 47 & $"$ & 2 & $\begin{array}{l}\text { Maxim Siergiel (50), żona Justyna (35), syn } \\
\text { Hryszko (16), Kostuś (9) }\end{array}$ & 1 & 3 \\
\hline
\end{tabular}

\section{[k. 7v] Powinność włościan tejże wsi Skarczewa}

Ludzie tej wsi trzymający i zarabiający po pół włóki gruntu, mężczyzna dwa, a kobieta dzień w każdym tygodniu służą pańszczyzną. Nadto od zaczęcia roboty około siana aż do ukończenia żniwa służą gwałty, czyli tłokę, które wówczas razem z pańszczyzną w tydzień wypadają na mężczyznę po dni trzy, a na kobietę po dwa dni. Stróżę i nocną wartę po dwóch przychodząc, kolejno w plebanii odbywają.

\section{Inwentarz mieszkańców miasteczka Kroszyna przez Sąd Taksatorsko-} -Eksdywizorski Dóbr zeszlego księcia Macieia Radziwiłła ${ }^{24}$ kasztelana wileńskiego w Połoneczce odbyty, za summę funduszową na schedę plebanii kroszyńskiej wydzielonych;

1. Mateusz Naszukiewicz, żona Magdalena, synów 3: Wincenty, Mikołaj, Jan; córka Katarzyna; braci 2: Symon, żona Marianna, syn Józef, córek 2: Agata i Anna; 2-gi brat Michał.

2. Mikołaj Szyszłowski, żona Klara, synów 3: Jan, Andrzej, Fabian; córka Marianna, szwagier Antoni.

3. Jan Naszukiewicz, żona Barbara, syn Ignacy, żona Anna.

${ }^{24}$ Radziwiłł Maciej, książę, kasztelan wileński (1749-1800) - kompozytor, polityk, w latach 1786-1795 podkomorzy wielki litewski, w 1790 roku kasztelan wileński, członek Zgromadzenia Przyjaciół Konstytucji Rządowej i konfederacji targowickiej, wolnomularz, hrabia na Szydłowcu 1795-1800. Syn Leona Michała i Anny Ludwiki z Mycielskich. Po śmierci matki w 1771 roku otrzymał dobra litewskie, w tym wydzierżawione: Połoneczkę, Kroszyn i Husaków. Od 1773 roku osiedlił się w Połoneczce, gdzie rozpoczął szereg procesów z bratem Mikołajem, domagając się podziału dóbr macierzystych. Ożenił się z Elżbietą Chodkiewiczówną, z którą miał syna Krzysztofa i córkę Antoninę. Został odznaczony Orderem Św. Stanisława i Orła Białego. Por. Z. Anusiak, A. Stroynowski, Radziwilt Maciej h. Trąby, w: Polski Stownik Biograficzny, t. 30, Warszawa 1987, s. 285-288. 
4. Piotr Łukaszewicz, żona Agata, córka Józefa, brat Jan.

5. Mateusz Łukaszewicz, żona Teresa; syn Jan, żona Marianna, córka Petronela, syn Wincenty.

6. Katarzyna Szyszłowska, wdowa córka Marianna, zięć Maciej Wasilewski, żona jego Petronela, wnuki Jan, Kazimierz.

Powinność tych mieszkańcow, ich cały nieruchomy i ruchomy majątek pomienionym wyżej dekretem i inwentarzem przy nim podawczym obszernie i dokładnie jest opisana i poszczególniona, prócz tej powinności dworowi wedle dekretu winnej, wszystkie inne jako: propinacja, wybór podatków i egzekucja wszelkich rekwizycjów rządowych z tej schedy do dziedziców J[aśnie] O.O. [= Oświeconych] Ks[ią]żąt Radziwiłłów należą - równie i pobór rekruta, dla czego i skazkami u dziedziców objęci. Dusz zaś skazkowych plebanalnych z wsi Skarczewa i juryzdyki jest 168 . Pańszczyzny licząc z włóki wedle Inwentarza po dni cztery męskiej wypada na rok dni 6,148, z dodaniem 964 dni gwałtowych uczyni dni 5,712. Kobicie zaś panszczyźnianych dni 2,496, a z dodaniem 964 dni gwałtowych 3,060 dni ogółem czyni. Taksa dni męskich, biorąc w ogół letnie i zimowe, po złotym jednem. Kobicie zaś także w ogół złączone po pół złotego liczyć się mogą. Lecz tu intraty nie ma zwyczaju brać z robotnika, tylko z wysiewu.

\begin{tabular}{|c|c|c|c|c|c|}
\hline & \multicolumn{5}{|c|}{$\begin{array}{c}\text { [k. 8r; k. 8v] Wiadomość o summach kapitalnych funduszowych duchowieństwa } \\
\text { świeckiego diecezji rzymskokatolickiej wileńskiej lacińskiego obrządku }\end{array}$} \\
\hline \multirow{2}{*}{1} & $\begin{array}{l}\text { J a k i e j } \\
\text { diecezyi, } \\
\text { guberni, } \\
\text { powiatu, } \\
\text { kościoła, } \\
\text { klasztoru }\end{array}$ & & \multicolumn{3}{|c|}{$\begin{array}{l}\text { grodzieńskiej gubernii, nowogrodzkiego powiatu i dekanatu kroszyń- } \\
\text { skiego parafialnego kościoła }\end{array}$} \\
\hline & & & summa pewna 1 & $\begin{array}{l}\text { summa } \\
\text { pewna } 2\end{array}$ & summa niepewna \\
\hline 2 & $\begin{array}{lr}\text { W jakiej } \\
\text { ilości na- } \\
\text { dany ka- } \\
\text { pitał i w } \\
\text { jakiej mo- } \\
\text { necie? } \\
\end{array}$ & $\begin{array}{l}\text { r u b le } \\
\text { srebrne }\end{array}$ & 750 & 300 & 750 \\
\hline
\end{tabular}




\begin{tabular}{|c|c|c|c|c|c|}
\hline 3 & \multicolumn{2}{|c|}{$\begin{array}{l}\text { Jakiego rodzaju jest } \\
\text { funduszowy kapitał } \\
\text { i przez kogo nada- } \\
\text { ny? Na czem za- } \\
\text { bezpieczony, jakie } \\
\text { służą dokumenta? } \\
\text { Czyli nie są ob- } \\
\text { ciążone maiątki, } \\
\text { na których kapitał } \\
\text { oparty innemi dłu- } \\
\text { gami, lub czyli nie } \\
\text { naznaczone na roz- } \\
\text { dział kredytorów z } \\
\text { uszczerbkiem fun- } \\
\text { duszu? }\end{array}$} & $\begin{array}{l}\text { Summa funduszo- } \\
\text { wa dziesięcinę przez } \\
\text { fundatora Joskę } \text { Goy- } \\
\text { cewicza pod rokiem } \\
1442 \text { przeznaczoną, a } \\
\text { przez ks[ię]cia Karola } \\
\text { Zygmunta Radziwiłła } \\
\text { na summę pieniężną } \\
\text { złot[ych] } 5000 \text { pod ro- } \\
\text { kiem } 1646 \text { zamieniona } \\
\text { i na dobrach Kroszynie } \\
\text { oparta. Majątek ten po } \\
\text { obciążeniu dalszemi } \\
\text { długami od roku } 1804{ }^{\circ} \\
\text { pod doczesnym rozbio- } \\
\text { rem w różnych zostaje. }\end{array}$ & 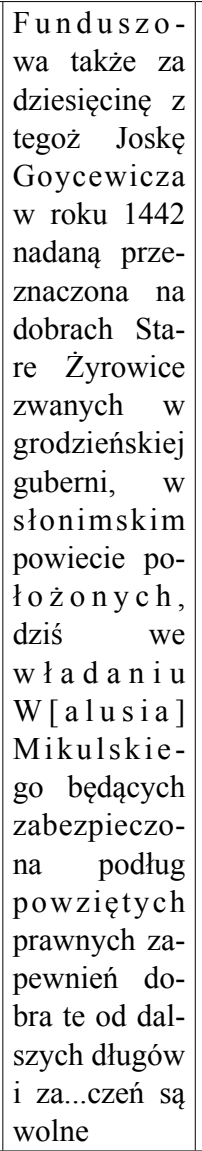 & $\begin{array}{l}\text { Summa legacyjna za skra- } \\
\text { dzione przez Żydów La- } \\
\text { chowieckich kościelne ru- } \\
\text { chomosci, od kahału winna } \\
\text { księdzu Jakubowi Janowi } \\
\text { Glince plebanowi kroszyń- } \\
\text { skiemu roku } 1687 \text { obligiem } \\
\text { na tymże kahale obezpieczo- } \\
\text { na. Ewikcja z powodu dłu- } \\
\text { gów i ubóstwa tego kahału } \\
\text { niepewna i zawodna }\end{array}$ \\
\hline 4 & $\begin{array}{l}\text { Ile mia- } \\
\text { n o w i c i e } \\
\text { należy do } \\
\text { d u c h o - } \\
\text { wieństwa } \\
\text { k a p i - } \\
\text { t a l n y c h } \\
\text { summ fun- } \\
\text { duszowych } \\
\text { które mogą } \\
\text { być prze- } \\
\text { noszone na } \\
\text { inne ewik- } \\
\text { cye? }\end{array}$ & $\begin{array}{l}\mathrm{r} \text { u b l le } \\
\text { srebrne }\end{array}$ & 750 & 300 & 750 \\
\hline
\end{tabular}




\begin{tabular}{|c|c|c|c|c|}
\hline 5 & $\begin{array}{l}\text { Ile duchowieństwo } \\
\text { ma takich summ } \\
\text { które do jednego } \\
\text { miejsca na zawsze } \\
\text { przywiązane? }\end{array}$ & może bydź zdiętą & $\begin{array}{l}\text { może bydź } \\
\text { przeniesioną }\end{array}$ & $\begin{array}{l}\text { może bydź przeniesiona na } \\
\text { inne miejsce }\end{array}$ \\
\hline 6 & $\begin{array}{l}\text { Jaki duchowieństwo } \\
\text { pobiera procent od } \\
\text { tych sum? }\end{array}$ & 8 & 5 & 3 \\
\hline 7 & $\begin{array}{l}\text { Jeżeli procenta } \\
\text { opłacane są mniej- } \\
\text { sze niż prawne lub } \\
\text { nie opłacaią się, } \\
\text { więc dlaczego? } \\
\text { Gdzie o nie toczy } \\
\text { się proceder? }\end{array}$ & dochodzi & dochodzi & $\begin{array}{l}\text { Nie dochodzi od niepamięt- } \\
\text { nych lat, proceder o to toczy } \\
\text { się w ziemstwie Słuckim }\end{array}$ \\
\hline & Summ pewnych & \multicolumn{2}{|c|}{1050} & \\
\hline & Summy niepewnej & & & 750 \\
\hline & Ogólem & \multicolumn{3}{|c|}{1800} \\
\hline
\end{tabular}

\begin{tabular}{|c|l|c|}
\hline L.p. & \multicolumn{1}{|c|}{ [k. 9r] 80 Opisanie aktów parafialnych } & Sztuki \\
\hline 1 & $\begin{array}{l}\text { Inwentarz podawczy funduszu kroszynskiego zeszłego księdzu Karolowi Malinow- } \\
\text { skiemu pod rokiem 1764 sporządzony w oryginale sztuka }\end{array}$ & 1 \\
\hline 2 & $\begin{array}{l}\text { Inwentarz tegoż kroszyńskiego funduszu roku 1810 januarii 29 sporządzony przez } \\
\text { Śp. [= świętej pamięci] ks[ię]dza Jana Ćwirkę na ówczas dziekana nowogródzkie- } \\
\text { go, teraźniejszemu plebanowi W.J. ks[ię]dzu [Wojciechowi] Magnuszewskiemu } \\
\text { podający w oryginale, sztuka }\end{array}$ & 1 \\
\hline 3 & $\begin{array}{l}\text { Metryki parafialne od roku 1688o znajdują się w sześciu księgach koleją lat po so- } \\
\text { bie następujących aż do teraźniejszego czasu, to jest od lat 132. Wszystkie rodzaje } \\
\text { metryk zawieraią się w tych księgach sześciu }\end{array}$ & 6 \\
\hline
\end{tabular}

\begin{tabular}{|c|c|c|c|}
\hline \multicolumn{4}{|c|}{ 9o Osoby duchowne } \\
\hline 1 & imię i nazwisko & $\begin{array}{l}\text { pleban ks[ią]dz Woj- } \\
\text { ciech Magnuszewski }\end{array}$ & \begin{tabular}{|l|l|} 
komendarz ks[ią]dz Pius Horbaczewski \\
z Zakonu Kaznodziejskiego
\end{tabular} \\
\hline 2 & $\begin{array}{l}\text { Jakiego urodzenia } \\
\text { i z jakiego naro- } \\
\text { du? }\end{array}$ & $\begin{array}{l}\text { Polak urodzenia szla- } \\
\text { chetnego }\end{array}$ & Polak szlachetnego urodzenia \\
\hline 3 & Jakiego wieku? & Wieku lat 56 & Ma lat 45 \\
\hline 4 & $\begin{array}{l}\text { Gdzie, kiedy i } \\
\text { czego się uczył? }\end{array}$ & $\begin{array}{l}\text { Odbywał semina- } \\
\text { rium w Wilnie około } \\
\text { roku 1796. Uczył się } \\
\text { wszystkiego, cokol- } \\
\text { wiek z nauk duchow- } \\
\text { nych owego czasu w } \\
\text { seminarium dawano. } \\
\text { Uprzednie zaś odbywał } \\
\text { w Nowogródku }\end{array}$ & $\begin{array}{l}\text { Nowicjat odbywał w Litwie w Poporciach } \\
\text { w roku } 1805^{\underline{m}} \text {. Uczył się wszystkich nauk du- } \\
\text { chownych do zakonu należnych }\end{array}$ \\
\hline
\end{tabular}




\begin{tabular}{|c|c|c|c|}
\hline 5 & $\begin{array}{l}\text { Kiedy wstąpił w } \\
\text { stan duchowny, } \\
\text { gdzie, jakiego } \\
\text { czasu, jakie pełnił } \\
\text { duchowne urzę- } \\
\text { da i czy otrzymał } \\
\text { podw y żs zenie } \\
\text { w stopniach du- } \\
\text { chownych? }\end{array}$ & $\begin{array}{l}\text { Wyświęcił się na ka- } \\
\text { płaństwo w roku } 1793 \text {. } \\
\text { Był naprzód komen- } \\
\text { darzem przy kościele } \\
\text { Worończańskim, po- } \\
\text { tem plebanem nieh- } \\
\text { niewickim aż do roku } \\
\text { 1810. Odtąd aż po dziś } \\
\text { dzień plebanem w Kro- } \\
\text { szynie. Urzędów dla } \\
\text { niezdrowia żadnych } \\
\text { nie posiadał }\end{array}$ & $\begin{array}{l}\text { Wyświęcił się na kapłaństwo w roku } 1807 \text { m } \text {, ile } \\
\text { w zakonie urzędów znacznych pełnić nie mogł } \\
\text { i nic stałości stopniów zakonnych nie ma co } \\
\text { wypomnieć }\end{array}$ \\
\hline 6 & $\begin{array}{l}\text { Czy nie miał ja- } \\
\text { kich pouczeń i czy } \\
\text { nie był udzielnie } \\
\text { oprócz urzędów } \\
\text { duchownych czem } \\
\text { nadgrodzony i kie- } \\
\text { dy mianowicie? }\end{array}$ & $\begin{array}{l}\text { Dla naznaczonej wyż- } \\
\text { szej przyczyny, nie- } \\
\text { zdrowia, żadnych przy- } \\
\text { poruczeń spełnić nie } \\
\text { mogąc, nie był nigdy } \\
\text { do tego destynowanym }\end{array}$ & $\begin{array}{l}\text { Zakonnik żadnych przyporuczeń oprócz obo- } \\
\text { wiązków duchownych mieć nie mógł, a zatem } \\
\text { idącej stąd nadgrody }\end{array}$ \\
\hline 7 & $\begin{array}{l}\text { Czy nie był szt[r] } \\
\text { ofowany, kara- } \\
\text { ny? Jeśli był, za } \\
\text { co mianowicie, } \\
\text { kiedy, i iak dzieło } \\
\text { ukończone? }\end{array}$ & $\begin{array}{l}\text { Pod strafami i karami } \\
\text { nigdy nawet w dzieciń- } \\
\text { stwie swoim nie był }\end{array}$ & Sztrafowanym i pod karami nigdy nie był \\
\hline 8 & $\begin{array}{l}\text { Wiele otrzymuje } \\
\text { pensyi lub rocz- } \\
\text { nego dochodu? z } \\
\text { jakich miejsc i za } \\
\text { jakiem postano- } \\
\text { wieniem? }\end{array}$ & $\begin{array}{l}\text { Pensyi żadnej nie po- } \\
\text { biera i żadnego docho- } \\
\text { du prócz plebanalnego } \\
\text { nie ma }\end{array}$ & $\begin{array}{l}\text { Na pensją ma sobie od plebana ustąpieny do- } \\
\text { chód kościelny do sta zł[oty]ch wynoszący - } \\
\text { mogący wystarczyć na habit }\end{array}$ \\
\hline 9 & $\begin{array}{l}\text { Czy zdatny do } \\
\text { pełnienia nadal } \\
\text { obowiązkow? }\end{array}$ & $\begin{array}{l}\text { Obowiązki kapłańskie, } \\
\text { lubo przy wielkim nie- } \\
\text { zdrowiu, wypełniać } \\
\text { najregularniej stara się } \\
\text { i nadal nigdy nie prze- } \\
\text { stanie }\end{array}$ & $\begin{array}{l}\text { Póki zdrowie służy, zdolny będzie pełnić ka- } \\
\text { płańskie obowiązki }\end{array}$ \\
\hline
\end{tabular}

\begin{tabular}{|c|c|c|}
\hline L.p. & [k. 9v] 10ºpisanie biblioteki & Sztuki \\
\hline 1 & Mszałów starych in folio, sztuk trzy & 3 \\
\hline 2 & Mszałów starych także in $4^{\text {to }}$, trzy & 3 \\
\hline 3 & Mszalików żałobnych, starych, dwa & 2 \\
\hline 4 & Agentka in folio, stara, jedna. Ditto małych agendek dwie ogółem & 3 \\
\hline \multirow[t]{2}{*}{5} & Ewangeliczek kościelnych dwie & 2 \\
\hline & Ogółem książek sztuk trzynaście & 13 \\
\hline
\end{tabular}

Co do punktów $11^{\circ}, 12^{\circ}$ i $13^{\circ}$ ani altaryi, filii, ani też kaplicy żadnej w obrębie parafii kroszyńskiej nie masz ani fundusz żaden na one nie znajduje się. 


\section{4ㅇ Opisanie statystyczne parafii}

Rozległość parafi kroszyńskiej wzdłuż i wszerz rozciąga się na mil dwie 2. Graniczy z parafiami: stołowicką, darewską, swojatycką, snowską, zadwiejską i połoneczcką. Trakt pocztowy od Nieświża do Słonima idący na milę i nieco więcej ją przerzyna. Dwory i wsie do tej parafii należą poniższe: dwór Kroszyn, Stajki i Czernichów (33), miasteczko Kroszyn (82), gdzie kościół położony, wsie Zarowie (14), Hołubowszczyzna (7), Nowosady (9), Juszkiewicze (37), Kłompiki (17), Makasze (28), Dąbrowna (21), Kraszewo (47), dwory Kuniłow i Podlesie (45) z wsią tegoż imienia. Numera nad wsiami znaczą liczbę dymów.

W tychże wsiach i dworach w znacznej części znajdują się osoby wyznania rzymsko-unitskiego [s], nawet między familiami pomieszane, które udzielnie do swoich parafiów należą.

\begin{tabular}{|c|c|c|c|c|c|c|c|c|c|c|c|c|}
\hline \multicolumn{13}{|c|}{$\begin{array}{l}\text { Tabella obejmująca wiadomość statystyczną, wiele się liczy za rok } 1819 \text { w Kroszynie parafii } \\
\text { dekanatu nowogrodzkiego nowonarodzonych, zaślubionych itd. płci obojej po upływie tegoż } \\
\text { roku w dacie } 1820\end{array}$} \\
\hline \multicolumn{2}{|c|}{$\begin{array}{l}\text { nowonaro- } \\
\text { dzeni }\end{array}$} & \multirow{3}{*}{$\begin{array}{c}\text { zaślu- } \\
\text { bieni }\end{array}$} & \multirow{2}{*}{\multicolumn{2}{|c|}{$\begin{array}{l}\text { przystępuią- } \\
\text { cy do SSch } \\
\text { Sakramentów } \\
\text { płci }\end{array}$}} & \multirow{2}{*}{\multicolumn{2}{|c|}{$\begin{array}{l}\text { nieprzystępu- } \\
\text { jący do SS } \\
\text { Sakramentów } \\
\text { płci }\end{array}$}} & \multirow{2}{*}{\multicolumn{2}{|c|}{$\begin{array}{l}\text { umarli w } \\
\text { ogóle } \\
\text { płci }\end{array}$}} & \multicolumn{2}{|c|}{$\begin{array}{c}\text { ospa szcze- } \\
\text { piona }\end{array}$} & \multicolumn{2}{|c|}{$\begin{array}{l}\text { ogólna lud- } \\
\text { ność }\end{array}$} \\
\hline \multicolumn{2}{|c|}{ płci } & & & & & & & & & & & \\
\hline 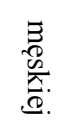 & 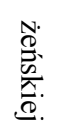 & & 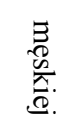 & 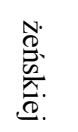 & 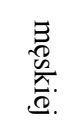 & 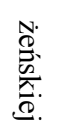 & 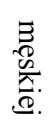 & 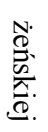 & 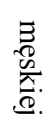 & 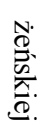 & 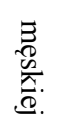 & 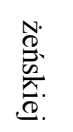 \\
\hline 43 & 36 & 14 & 611 & 677 & 184 & 183 & 14 & 15 & , & , & 838 & 896 \\
\hline
\end{tabular}

\begin{tabular}{|c|l|c|}
\hline & \multicolumn{1}{|c|}{ [k. 10r] 15o Opisanie dokumentów funduszowych } & Sztuki \\
\hline $\mathbf{1 4 4 2}$ & $\begin{array}{l}\text { roku fundusz kościoła kroszyńskiego od śp.[= świętej pamięci] Goycewicza fun- } \\
\text { dowanego autentyk w Archiwum Diecezjalnym a circa fundum }{ }^{\mathrm{a}} \text { kopia autoryzo- } \\
\text { wana znajduje się [dopisek ołówkiem: Nie ma takiej kopii] }\end{array}$ & 1 \\
\hline $\mathbf{1 6 2 6}$ & $\begin{array}{l}\text { Fundusz od zeszłego Xięcia Zygmunta Radziwiła }{ }^{\mathrm{b}} \text { na szpital kroszyński autentyk } \\
\text { w Archiwum Diecezjalnym a tu kopia }\end{array}$ & 1 \\
\hline
\end{tabular}

${ }^{\text {a }}$ Circa fundum (łac.) - odnośnie do fundacji (parafii).

b Radziwiłł Zygmunt Karol herbu Trąby (1591-1642), syn Mikołaja Krzysztofa zwanego Sierotką i Elżbiety z Wiśniowieckich, brat Albrechta Władysława, Aleksandra Ludwika i Jana Jerzego. Podkomorzy stołowicki od 1614 roku, od 1625 roku poznański, od 1617 roku krajczy koronny królowej, od 1633 roku krajczy wielki litewski, od 1638 roku podczaszy wielki litewski, od 1642 roku wojewoda nowogródzki. Wstąpił do Zakonu Maltańskiego. uzyskał wymagane w Zakonie oświadczenie urodzenia starożytnego szlachectwa a następnie, w 1610 roku, zapis wieczysty na ufundowanie dla niego komandorii na Litwie (majątek Stwołowicze, późniejsze Stołowicze oraz dobra Pociejki, po matce). Przez Kraków udał się na Maltę, gdzie w styczniu 1612 roku złożył śluby zakonne. W latach 1625-1642 był komandorem komandorii poznańskiej kawalerów maltańskich, a w latach 1616-1642 komandorem komandorii stwołowickiej. Zmarł w Asyżu. Por. T. Wasilewski, Radziwiłt Zygmunt Karol, PSB, t. 30 Warszawa 1987, s. 379-382. 


\begin{tabular}{|c|c|c|}
\hline 1687 & $\begin{array}{l}\text { Oblig od Żydow kahału lachowickiego, zeszłemu J. Xdzu [Janowi] Glince na } \\
\text { sumę 5,000 Złłch Polch [= złotych polskich] wydany. Autentyk w Archiwum Die- } \\
\text { cezjalnym a tu w Widymusie znajduje się }\end{array}$ & 1 \\
\hline 1697 & $\begin{array}{l}\text { Ugodliwy zapis zeszłego Xięcia Dominika Mikołaja Radziwiłłac J. Xdzu [Bo- } \\
\text { gusławowi] Wołkowi kanonikowi smoleńskiemu, na ówczas plebanowi kroszyń- } \\
\text { skiemu na summę } 5660 \text { Złłch Polch [= złotych polskich] za dziesięcinę z dworu } \\
\text { Kroszyńskiego kościołowi dawaną, i za karczmę w miasteczku Kroszynie fundu- } \\
\text { szem plebanii nadaną, wydany w kopii }\end{array}$ & 1 \\
\hline \multicolumn{2}{|r|}{$\begin{array}{l}\text { Na zł[oty]ch pol[ski]ch dwa tysiące na Starych Żyrowicach oparte, od których procent } \\
4^{\mathrm{ty}} \text { czyli Złłch [= złotuch] 80, terazniejszy dziedzic } \mathrm{W}^{叉} \text { Mikulski corocznie wypłaca, circa } \\
\text { fundum nie ma żadnego, ani nawet w kopii dokumentu - nie jest nawet wiadomo czy się } \\
\text { jakowy w Archiwum Diecezjalnym znajduje }\end{array}$} & $"$ \\
\hline 1804 & $\begin{array}{l}\text { Aprila } 16 \text { excerpt z protokułu sądów Taxatorsko Exdywizorskich in fundo dóbr } \\
\text { Połoneczki zeszłego Xięcia Macieja Radziwiłła kasztelana wilenskiego odbytych } \\
\text { - oczywistego dekretu w kategoryi zeszłego J. Xdza [Karola] Malinowskiego pro- } \\
\text { boszcza Kroszyńskiego w datcie powyższej zaszłego, którym za summę kapitalną } \\
\text { przez zeszłego Xdza Malinowskiego na wymórowanie kościoła początkowo } 8,640 \\
\text { Złłch Pollch [= złotych polskich] w roku jeszcze } 1777 \text { aprila } 17 \mathrm{~d}[\text { nia] zapisaną } \\
\text { i u zeszłego Xcia Macieja Radziwiłła kasztelana wilenskiego złożoną, znacznym } \\
\text { czasu przeciągiem z procentów i przezysków prawnych przeszło do } 30,000 \text { urosłą } \\
\text { sześciu mieszkańcow z miasteczka Kroszyna, który za powinność w inwentarzu } \\
\text { opisaną, czynszu Złłch Pollch [= złotych polskich] } 5768 / 2 \text { corocznie płacić są } \\
\text { obowiązani, oraz lasu brzozowego morgów } 24 \text {, prętów } 61 \text { na do kompletowanie } \\
\text { intraty przysądzono. Tegoż aprila } 20 \text { w skutek tegoż dekretu inwentarz podawczy } \\
\text { z zupełnym opisaniem stanu i majątku schedy urzędownie wydanej }\end{array}$ & 2 \\
\hline
\end{tabular}

Prócz tych poszczególnionych dokumentow żadnych innych circa fundum plebanii kroszyńskiej nie masz.

\section{[k. 10v] 16. Opisanie szkółki parafialnej kroszyń́skiej}

Ta szkółka od roku 1810-o egzystuje. Funduszu na nią żadnego nie ma, lecz kosztem teraźniejszego plebana, W[ielmożnego] J[egomości] Ks[ię]dza Magnuszewskiego utrzymuie się. Nauczycielem tej szkółki jest dawniejszy onej uczeń Daniel Siergiel, wyznania katolickiego. Nie posiada on żadnych wyższych klasycznych nauk, lecz umie dobrze czytać, pisać i początkowe rachunki robi, do tegoż uczniów swej szkółki przykłada, sam zaś z niektóremi dawniejszemi współuczniami wyżej w tychże naukach ... się. Wszyscy zostają pod pilnym i czułym dozorem swego pracodawcy, miejscowego plebana. Liczba uczniów, po większej częsci z parafian włościan kroszynskich złożona - w obojej płci osób 91 wynosi - których imiona następne porządkiem alfabetu:

${ }^{\mathrm{c}}$ Radziwiłł Dominik Mikołaj herbu Trąby (1653-1697), syn Aleksandra Ludwika i jego trzeciej żony Lukrecji Marii ze Strozzich. Z wdzięczności za jego uzdrowienie w 1668 roku matka ufundowała klasztor dominikanów w Pińsku. Po śmierci w 1690 roku żony Anny Marianny z Połubińskich, Dominik Mikołaj ożenił się w 1692 roku z Anną Krystyną z Lubomirskich. Na jego dobra składały się dobra przekazane mu przez brata Michała Kazimierza w wyniku ugody zawartej w 1671 roku: Szydłowiec, Czernawczyce, Kroszyn z Kołdyszewem i Stajkami, Żułów i Rzesza oraz starostwo grodowe lidzkie. Por. A. Rachuba, Radziwitt Dominik Michat h. Trąby, PSB, t. 30, s. 173-176. 


\begin{tabular}{|c|c|c|c|c|c|}
\hline \multicolumn{6}{|c|}{ Pleć męska } \\
\hline L.p. & & Wiek & L.p. & & Wiek \\
\hline 1 & Andruszkiewicz Jan & 11 & 32 & Kobiak Roman & 10 \\
\hline 2 & Andruszkiewicz Julian & 8 & 33 & Kobiak Grzegorz & 9 \\
\hline 3 & Bahrym Paweł & 8 & 34 & Leusz Kazimierz & 9 \\
\hline 4 & Ciechanowicz Antoni & 13 & 35 & Lickiewicz Aleksander & 12 \\
\hline 5 & Filipowicz Michał & 13 & 36 & Lenczyc Jan & 8 \\
\hline 6 & Hryhorowicz Aleksander & 6 & 37 & Łukaszewicz Michał & 10 \\
\hline 7 & Hryhorowicz Bazyli & 10 & 38 & Łukaszewicz Józef & 9 \\
\hline 8 & Hryhorowicz Józef & 13 & 39 & Łukaszewicz Józef 2-gi & 9 \\
\hline 9 & Hryhorowicz Wincenty & 10 & 40 & $\begin{array}{l}\text { Łukaszewicz Aleksan- } \\
\text { der }\end{array}$ & 9 \\
\hline 10 & Hryhorowicz Jan & 13 & 41 & Łukaszewicz Wincenty & 5 \\
\hline 11 & Hermanowicz Wincenty & 8 & 42 & Ławrycki Marcin & 6 \\
\hline 12 & Iwanowski Józef & 10 & 43 & $\begin{array}{l}\text { Naszukiewicz Kazi- } \\
\text { mierz }\end{array}$ & 6 \\
\hline 13 & Iwanowski Józef 2-gi & 7 & 44 & Orłowski Jan & 17 \\
\hline 14 & Januszkiewicz Hieronim & 10 & 45 & Orłowski Jerzy & 14 \\
\hline 15 & Januszkiewicz Józef & 7 & 46 & Orłowski Józef & 9 \\
\hline 16 & Januszkiewicz Wincenty & 9 & 47 & Orłowski Józef & 6 \\
\hline 17 & Jelecki Jan & 16 & 48 & Parfimowicz Jan & 12 \\
\hline 18 & Jelecki Gabriel & 16 & $\begin{array}{c}\text { [k. 11r] } \\
49\end{array}$ & Rusiecki Jan & 6 \\
\hline 19 & Jelecki Bazyli & 21 & 50 & Raczkowski Mikołay & 9 \\
\hline 20 & Kazimierski Onufry & 10 & 51 & Radecki Wincenty & 10 \\
\hline 21 & Kamiński Adam & 11 & 52 & Sarosiek Julian & 8 \\
\hline 22 & Kisielewicz Jan & 11 & 53 & Siergiel Teodor & 17 \\
\hline 23 & Kisielewicz Michał & 5 & 54 & Siergiel Daniel & 17 \\
\hline 24 & Krućko Bazyli & 17 & 55 & Siergiel Jan & 9 \\
\hline 25 & Krućko Maciej & 17 & 56 & Siergiel Konstanty & 16 \\
\hline 26 & Krućko Teodor & 12 & 57 & Siergiel Paweł & 9 \\
\hline 27 & Krućko Paweł & 7 & 58 & Turko Jan & 11 \\
\hline 28 & Krućko Józef & 9 & 59 & Turko Józef & 9 \\
\hline 29 & Krućko Grzegorz & 16 & 60 & Wasilewski Jan & 9 \\
\hline 30 & Krućko Sylwester & 12 & 61 & Wasilewski Aleksander & 17 \\
\hline 31 & Kobiak Symon & 10 & 62 & Wojtowicz Jan & 14 \\
\hline \multicolumn{6}{|c|}{ Pleć żeńska } \\
\hline 1 & Bahrymówna Anna & 9 & 16 & Kamińska Elżbieta & 5 \\
\hline 2 & Bahrymówna Teresa & 6 & 17 & Łukaszewicz Petronela & 6 \\
\hline 3 & Hryhorowicz Maria & 12 & 18 & Łukaszewicz Anna & 11 \\
\hline 4 & Hryhorowicz Katarzyna & 9 & 19 & $\begin{array}{l}\text { Łukaszewicz Magdale- } \\
\text { na }\end{array}$ & 8 \\
\hline 5 & Hryhorowicz Katarzyna & 7 & 20 & Machnaczówna Maria & 5 \\
\hline 6 & Hryhorowicz Anna & 5 & 21 & Naszukiewicz Anna & 8 \\
\hline 7 & Hryhorowicz Elżbieta & 7 & 22 & Orłowska Maria & 8 \\
\hline
\end{tabular}




\begin{tabular}{|c|l|c|c|l|c|}
\hline 8 & Jewsiejczykówna Elżbieta & 5 & 23 & Szarejkówna Katarzyna & 11 \\
\hline 9 & Jelecka Antonina & 10 & 24 & Szyłówna Anna & 9 \\
\hline 10 & Jelecka Teofila & 12 & 25 & Szyszłowska Anna & 7 \\
\hline 11 & Jelecka Barbara & 7 & 26 & Sobkówna Anna & 5 \\
\hline 12 & Jermakowska Magdalena & 12 & 27 & Sobkówna Maria & 8 \\
\hline 13 & Jermakowska Barbara & 9 & 28 & Wieliczkówna Wiktoria & 7 \\
\hline 14 & Kobiakówna Agata & 16 & 29 & Żukowska Barbara & 7 \\
\hline 15 & Krućkówna Aksienia & 13 & \multicolumn{5}{|l}{}
\end{tabular}

Zdatność w niektórych chociaż początkowych jeszcze znaczna okazuje się, konduity zaś lubo w tej prostej kondycyi stanu nagannej nie widzi. Miejsce szkółki iest połowa nowo zabudowanego szpitala.

\section{Opisanie szpitala}

W końcu juryzdyki plebańskiej na placu przez zeszłego Śp[= świętej pamięci] Zygmunta Radziwiłła w roku 1626 na szpital nadanym dla ubogich ku posłudze kościołowi kosztem teraźniejszego plebana wybudowany dopiero dom nowy, z drzewa brusowego heblowanego wystawiony, gontami pokryty. Budynek [k. 11v] w połowie obróconym jest na szpital, druga zaś połowa służyć będzie na szkółkę parafialną. Równo z nadaniem placu na szpital przez tegoż księcia Zygmunta Radziwiłła zrobiony fundusz na utrzymanie ubogich. A ten był: żyta beczek trzy, jęczmienia tyleż, słodu pół beczki, słoniny połeć, sadło jedne, soli garcy sześć, masła garniec jeden, serów sztuk dziesięć, maku garcy dwa, konopi ćwierć jedna. Czego egzekucja jeżeli była kiedy, więc już bardzo dawno ustała. Dzisiaj kilku ubogich chlebem plebana karmieni.

Wyciąg intraty rocznej, tak z wysiewu, jako i z dalszych źródel wchodzącej do plebanii kroszyńskiej oraz kalkulacja rozchodu z onej

\begin{tabular}{|c|c|c|c|c|}
\hline \multicolumn{5}{|c|}{ Przychód } \\
\hline \multirow{3}{*}{ 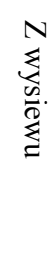 } & \multirow[t]{2}{*}{ 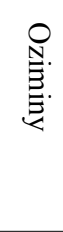 } & \multicolumn{2}{|c|}{$\begin{array}{l}\text { Żyta bek } 20 \% \text { garcy } 7 \text { (licząc w roku urodzajnym) prócz jednego } \\
\text { na odsiew po ziarn } 4 \text { uczyni bek } 83^{1 / 1} \text { garcy } 10 \text {, które licząc wedle } \\
\text { terazniejszej ceny po rubli } 4 \text {-ry uczynią rubli } 332 \mathrm{kpk} \text { [= kopiejek] } 80\end{array}$} & \multirow[t]{2}{*}{37459} \\
\hline & & \multicolumn{2}{|c|}{$\begin{array}{c}\text { Pszenicy bek } 12 /{ }_{8} \text { garcy } 8 \text { na toż } 4 \text { ziarno: prócz odsiewu uczyni bek } \\
51 / 8 \text { garcy } 14 \text {, którą po } 8 \text { rubli licząc uczyni } 41 \text { kpk } 79\end{array}$} & \\
\hline & \multicolumn{3}{|c|}{ z jarzyny choć tyle nie wynosi, lecz podług zwyczaju drugie tyle w oziminie } & 37459 \\
\hline \multicolumn{4}{|c|}{$\begin{array}{l}\mathrm{Z} \text { dalszych wszelkich gospodarskich przychodów akcydensów kościelnych pro- } \\
\text { centu pobieranego od kapitału - słowem wszelki resztuiący przychód }\end{array}$} & 250 \\
\hline \multicolumn{4}{|c|}{$\begin{array}{l}\text { Ogółem całego rocznego przychodu mieć może pleban rubli srebrnych tysiąc i to } \\
\text { nie zawsze }\end{array}$} & 1000 \\
\hline \multicolumn{5}{|c|}{ Rozchód z tych } \\
\hline \multicolumn{3}{|c|}{ Na opłatę podatków monarszych, ziemskich powinności } & RS 260 & \multirow{3}{*}{ R. 1000} \\
\hline \multicolumn{3}{|c|}{ Na utrzymanie kościoła, komendarza i sług kościelnych } & 200 & \\
\hline \multicolumn{3}{|c|}{ Resztujące na erekcją fundi, utrzymanie gospodarki i własne życie } & 540 & \\
\hline
\end{tabular}

Do oszczędzenia zatem na nowy kapitał nic nie zostaje. 
Takowy akt wizyty generalnej za rok 1820 -y odbytej, w czterech egzemplarzach przeze mnie przejrzany $i$ we wszystkim zgodny $z$ istotnym [k. 12r] stanem całego funduszu, podług prawa pieczęcią urzędu mego i podpisem ręki własnej stwierdzam. Dan w kroszyńskiej rzymskiej plebanii 1820-o roku, listopada 20-o dnia.

Kanonik miński dziekan nowogródzki, pleban iszkołdzki, jeneralny wizytator ksiądz Walenty Zan ${ }^{25}$.

1825 r[ok]u, dnia 12 maja w czasie wizyty jeneralny wizytator Ludwik Pawłowicz ${ }^{26}$ inwentarz kościoła i funduszu plebanii kroszyńskiej przejrzał i własnoręcznie się podpisał, przy wyciśnieniu herbowej pieczęci. Datum ut supra ${ }^{27}$ w Kroszynie.

\section{Ks. Ludwik Pawłowicz, wizytator}

Słowa kluczowe: wizytacja kościoła; historia Kresów Wschodnich; diecezja wileńska; parafia Kroszyn

\section{BIBLIOGRAFIA}

\section{Opracowania}

Anusiak Zbigniew, Andrzej Stroynowski, Radziwiłł Maciej h. Trąby, w: Polski Słownik Biograficzny, t. 30, s. 285-288.

Brzozecki Sławomir, Maciej, Maciej z Wilna, Maciej z Trok, w: Encyklopedia Katolicka, t. 11 Lublin 2006, kol. 705-706.

Encyklopedia wiedzy o jezuitach na ziemiach Polski i Litwy 1564-1995, red. L. Grzebień, Kraków 1996.

Kurczewski Jan, Biskupstwo Wileńskie, Wilno 1912.

Litak Stanisław, Kościół łaciński w Rzeczypospolitej około 1772 roku, Lublin 1996.

Misiurek Jerzy, Łoziński Zygmunt, w: Encyklopedia Katolicka, t. 11, Lublin 2006, kol. 554-555.

${ }^{25}$ Ks. Jan Walenty Zan - stryj Tomasza Zana (1796-1858, poety, współzałożyciela Towarzystwa Filomatów w 1819 roku, członka Towarzystwa Szubrawców, wolnomularz), kanonik miński, dziekan nowogródzki, prepozyt i administrator iszkołdzki, proboszcz w Iszkołdzi. Dnia 22 V 1821 roku ks. Jan Walenty Zan dokonał poświęcenia kościoła parafialnego pw. Bożego Ciała w Kroszynie, wybudowanego przez administratora kroszyńskiego ks. Wojciecha Magnuszewskiego. Ks. Jan W. Zan został pochowany w Iszkołdzi, tam też spoczywa brat Tomasza Zana. W Iszkołdzi niejednokrotnie odwiedzał księdza-stryja Tomasz Zan. Zachowały się o tym wzmianki w Korespondencji Filomatów w 1820, 1821 i 1822 roku. Filomaci na prowincji, opracowała M. Dunajówna, „Biblioteka Paradni Dydaktyczno-Wychowawczej Kuratorium Okręgu Szkolnego Wileńskiego”, Nr 10, Wilno 1935, s. 20.

${ }^{26}$ Ks. Pawłowicz Ludwik - profesor wymowy kościelnej (homiletyki) i prawa kościelnego w seminarium duchownym wileńskim i egzaminator diecezjalny.

${ }^{27}$ Datum ut supra (łac.) - datowane jak wyżej. 
Rachuba Andrzej, Radziwił Dominik Michał h. Trąby, w: Polski Słownik Biograficzny, t. 30, Warszawa 1987, s. 173-176.

Słownik Geograficzny Królestwa Polskiego i innych krajów słowiańskich, t. 4 red. F. Sulmierski i in., Warszawa 1883, s. 710-711.

\title{
Netografia
}

Radziwił Konstanty Mikołaj - www.geni.com/people/Konstanty-Mikołaj-Radziwił/6000000002367834005 (dostęp: 04.10.2016)

Kazimierz Rdułtowski - http://polesie.org/2036/o-dawnych-wlascicielach-juszkiewicz-czernichowa-adachowszczyzny/ (dostęp: 04.10.2016)

\section{THE VISITATION OF THE PARISH CHURCH IN KROSZYN IN THE DIOCESE OF VILNIUS OF 1820}

\begin{abstract}
Summary
The manuscript of the general visitation in the parish of Kroszyn of 20 November 1820 , conducted by the canon of Mińsk, the dean of Nowogródek, the parish priest in Iszkołdź - Rev. Walenty Zan, contains all historical data, personal information and statistics on the parish church and its equipment, church ministry, parishioners, church property, the description of the parish priest's land and census of the parishioners. Valuable information relates to organizing, by the then parish priest Rev. Magnuszewski, the parish school in 1810 in Kroszyn with the exact description of its students, their age and gender. The parish of Kroszyn also boasted a newly built hospital for the poor. The same text of the general visitation of 1820 was reviewed and signed by the person who conducted the next general visitation in 1825 .
\end{abstract}

Keywords: church visitations; the history of the Polish Eastern Borderlands; the Diocese of Vilnius; the parish of Kroszyn 